\title{
Spacer Conjugation and Surface Support Effects in Monolayer Electrochromic Materials.
}

Nadia O. Laschuk, Adaobi Obua, Iraklii I. Ebralidze, Holly M. Fruehwald, Jade Poisson, Jacquelyn G. Egan, Franco Gaspari, Fedor Y. Naumkin, E. Bradley Easton, and Olena V. Zenkina*

Faculty of Science, University of Ontario Institute of Technology, 2000 Simcoe Street North, Oshawa, ON, Canada

*Corresponding Author. E-mail: olena.zenkina@uoit.ca

\section{Supporting Information}

\section{Content}

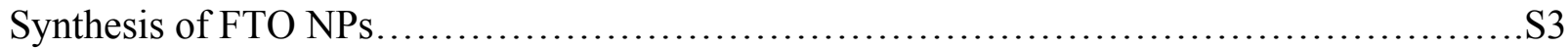

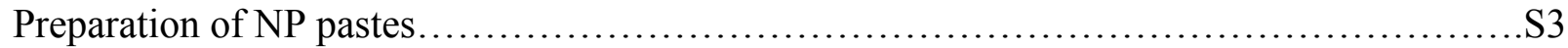

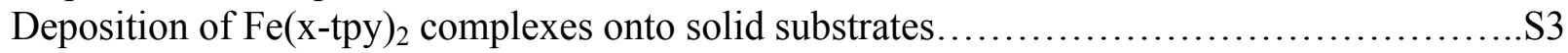

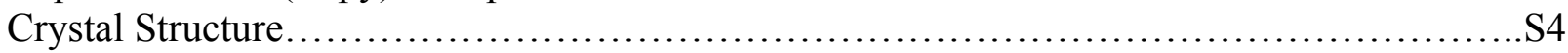

Figure S1. Crystallographically determined structure of $\left[\mathrm{Fe}(\mathrm{s}-\mathrm{Tpy})_{2}\right]\left(\mathrm{BF}_{4}\right)_{2} \ldots \ldots \ldots \ldots \ldots \ldots \mathrm{S} 4$

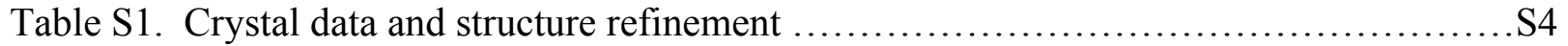

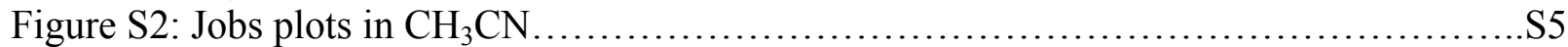

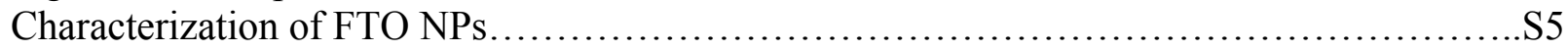

Figure S3: XRD patterns and BET isotherm for FTO NPs.............................. 5

Figure S4: Durability at $100 \mathrm{mV} / \mathrm{s}$, Nyquist plot, and capacitance plot for

FTO NPs screen-printed film on FTO/glass substrate................................... 6

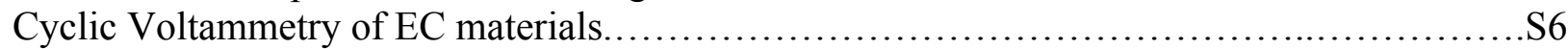

CV of ITO-30 NPs on ITO/Glass Substrate...........................................S7

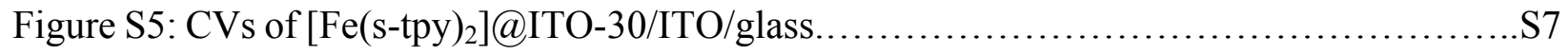

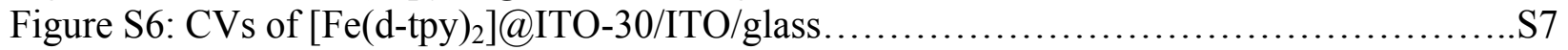

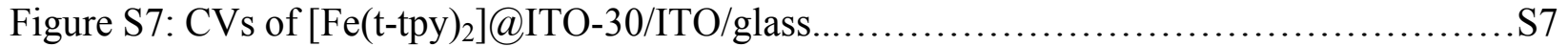

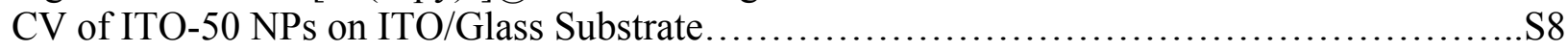

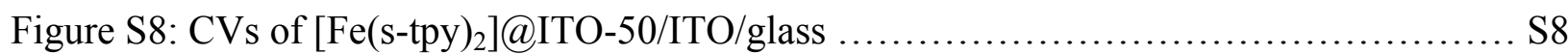

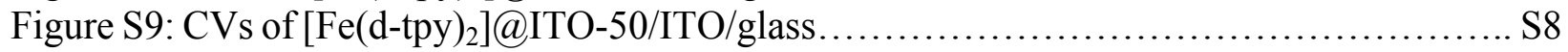

CV of FTO NPs on ITO/Glass Substrate ................................................ S8

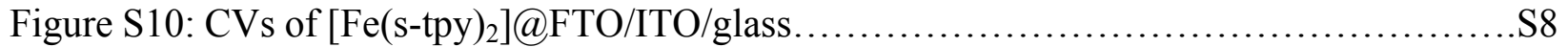

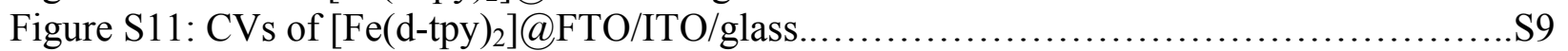

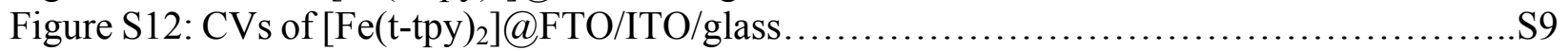

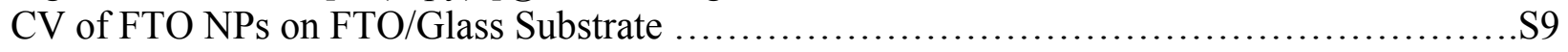

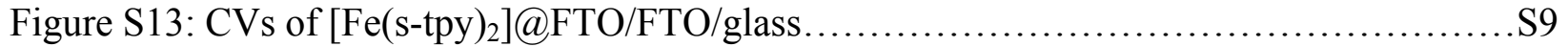

Figure S14: CVs of $\left[\mathrm{Fe}(\mathrm{d}-\mathrm{tpy})_{2}\right] @$ FTO/FTO/glass............................................

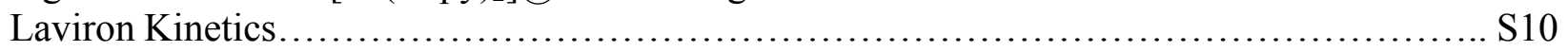

Figure S15: Laviron plots for Fe(s-tpy $)_{2}$ deposited on different substrates..................S10

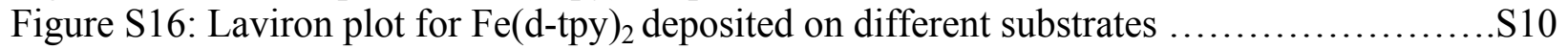

Figure S17: Laviron plot for Fe(t-tpy) $)_{2}$ deposited on different substrates $\ldots \ldots \ldots \ldots \ldots \ldots \ldots \ldots . . . .510$

Figure S18: Spectroelectrochemical (SEC) cycling of Fe(s-Tpy) 2 on different substrates ......S11 
Figure S19: SEC cycling of Fe(d-Tpy $)_{2}$ deposited on different substrates $\ldots \ldots \ldots \ldots \ldots \ldots \ldots$. 12

Figure S20: SEC cycling of Fe(t-Tpy $)_{2}$ deposited on different substrates $\ldots \ldots \ldots \ldots \ldots \ldots . . . . . . . . .313$

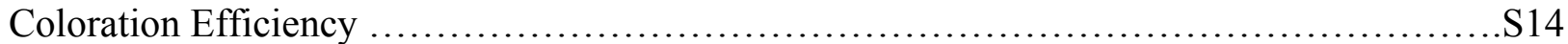

Figure S21: Coloration efficiencies for Fe(s-tpy) on different substrates ....................S14

Figure S22: Coloration efficiencies for Fe(d-tpy) on different substrates ....................S14

Figure S23: Coloration efficiencies for Fe(t-tpy) on different substrates . ...................S14

Figure S24. Contact angle of acetonitrile drop $(1 \mu \mathrm{L})$ on ITO/glass and FTO/glass

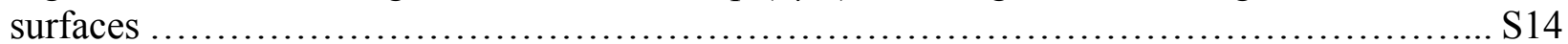

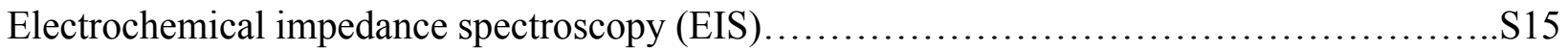

Figure S25: EIS data for Fe(t-tpy) on different substrates................................

Figure S26: The relationship between impedance and reciprocal square root of frequency.....S16

Figure S27: Charge distribution in monomethylated complexes.........................S16

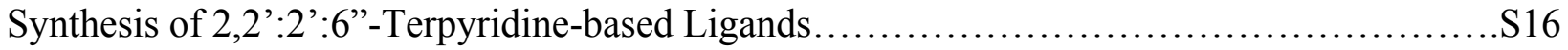

(E)-4'-(4-(2-(pyridin-4-yl)vinyl)phenyl)-2,2':6',2"-terpyridine aka d-tpy....................S16

4'-(4-(2-(pyridin-4-yl)ethyl)phenyl)-2,2':6',2"-terpyridine aka s-tpy ......................... 17

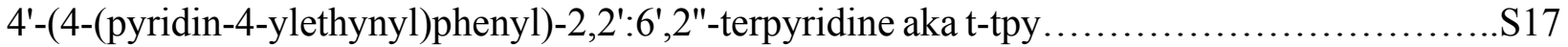

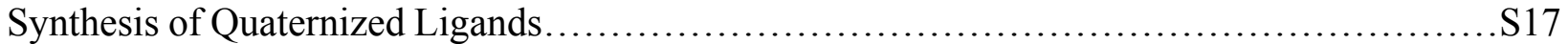

(4-(4-([2,2':6',2"-terpyridin]-4'-yl)phenethyl)-1-methylpyridin-1-ium)I...................S18

((E)-4-(4-([2,2':6',2"-terpyridin]-4'-yl)styryl)-1-methylpyridin-1-ium)I...................S18

(4-((4-([2,2':6',2"-terpyridin]-4'-yl)phenyl)ethynyl)-1-methylpyridin-1-ium)I...............S18

Synthesis of Iron(II)-Terpyridine Metal Complexes..................................... 18

[Fe(4'-(4-(2-(pyridin-4-yl)ethyl)phenyl)-2,2':6',2"-terpyridine $\left.)_{2}\right]\left(\mathrm{BF}_{4}\right)_{2}$

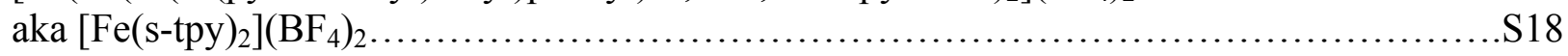

$\left[\mathrm{Fe}((E)-4 \text { '-(4-(2-(pyridin-4-yl)vinyl)phenyl)-2,2':6',2"-terpyridine })_{2}\right]\left(\mathrm{BF}_{4}\right)_{2}$

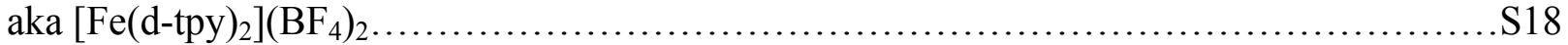

[Fe(4'-(4-(pyridin-4-ylethynyl)phenyl)-2,2':6',2"-terpyridine) $\left.)_{2}\right]\left(\mathrm{BF}_{4}\right)_{2}$

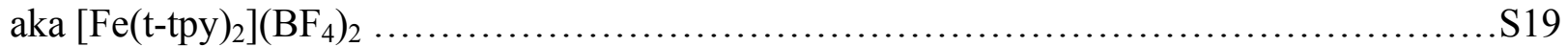

[Fe(4-(4-([2,2':6',2"-terpyridin]-4'-yl)phenethyl)-1-methylpyridin-1-ium) $]_{2} \mathrm{I}_{2}\left(\mathrm{BF}_{4}\right)_{2}$

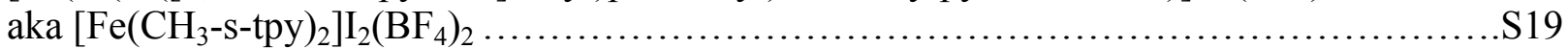

$\left[\mathrm{Fe}\left((E)-4-\left(4-\left(\left[2,2^{\prime}: 6^{\prime}, 2^{\prime \prime}-\text { terpyridin }\right]-4^{\prime} \text {-yl)styryl)-1-methylpyridin-1-ium }\right) \mathrm{I}\right]_{2}\left(\mathrm{BF}_{4}\right)_{2}\right.\right.$

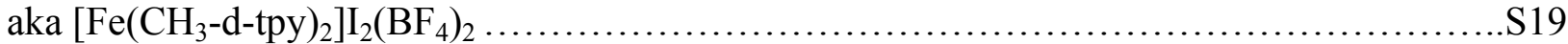

[Fe((4-((4-([2,2':6',2"-terpyridin]-4'-yl)phenyl)ethynyl)-1-methylpyridin-1-ium)I $)]_{2}\left(\mathrm{BF}_{4}\right)_{2}$

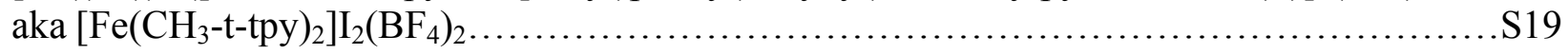

Figure S28: CVs of $0.1 \mathrm{mM}$ complexes in $0.1 \mathrm{M}$ TBAHFP/MeCN solution...................S20

Figure S29: IR spectra of tpy ligands and Fe-tpy complexes............................S20

Figure S30: ${ }^{1} \mathrm{H} \quad$ NMR $\quad$ spectrum $\quad$ of

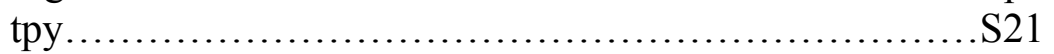

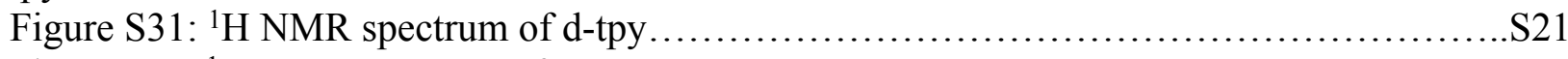

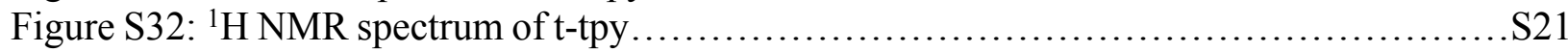

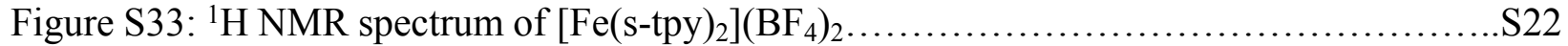

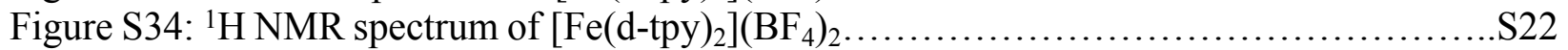

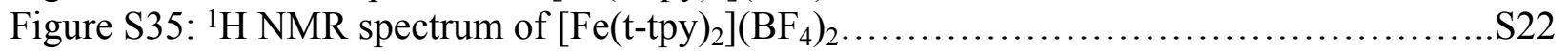

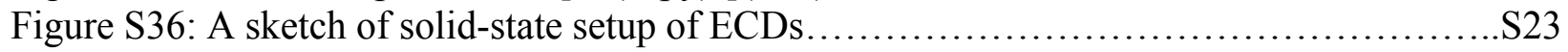

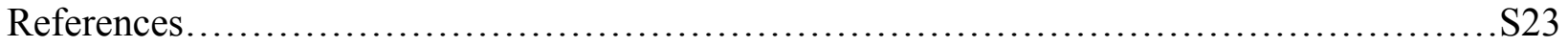




\section{Synthesis of FTO NPs.}

WARNING: HF can be fatal upon contact. A face shield, rubber gloves, and rubber apron were worn in addition to the standard laboratory safety gear. A contact of HF-containing mixtures with any glass or metal parts should be avoided.

$\mathrm{SnCl}_{2} \cdot 2 \mathrm{H}_{2} \mathrm{O}, 5.05 \mathrm{~g}(22.4 \mathrm{mmol})$ and $0.33 \mathrm{~mL}$ of $48 \% \mathrm{HF}$ solution $(9.11 \mathrm{mmol})$ were added to $100 \mathrm{~mL} \mathrm{H}_{2} \mathrm{O}$. A mixed solution of $5.0 \mathrm{~mL}$ acetylacetone $(49 \mathrm{mmol})$ in $14 \mathrm{~mL}$ of methanol was added to the $\mathrm{SnCl}_{2} \cdot 2 \mathrm{H}_{2} \mathrm{O}$ and $\mathrm{HF}$ solution dropwise over 45 minutes using rapid stirring. $50 \%$ $\mathrm{NH}_{4} \mathrm{OH}_{(\text {aq) }}$ was added dropwise until gel formation occurred. The dropping rate was monitored until $\mathrm{pH} 9.5$, and the resulting milky white gel solution was stirred overnight. The solution was filtered and washed several times with cold $\mathrm{H}_{2} \mathrm{O}$ to remove all $\mathrm{Cl}^{-}$ions, monitoring $\mathrm{Cl}^{-}$ion contamination using $0.1 \mathrm{M} \mathrm{AgNO}_{3(\mathrm{aq})}$. The product was dried in an oven at $100^{\circ} \mathrm{C}$ for $1 \mathrm{~h}$ prior to the addition of $2 \mathrm{~mL}$ methanol converting the dry powder to an alcogel. The final product was obtained after $2 \mathrm{~h}$ heating at $600^{\circ} \mathrm{C}$ then $700^{\circ} \mathrm{C}$. Yield: $2.67 \mathrm{~g}, 80 \%$.

\section{Preparation of NP pastes}

To prepare the ITO-50 and FTO NP pastes, $75 \mathrm{~mL}$ agate jars of PQ-N04 planetary ball milling system (Across International) were first rinsed with anhydrous ethanol. $18 \mathrm{~g}$ of $6 \mathrm{~mm}$ agate beads were added to one agate jar, and then rinsed with anhydrous ethanol and dried. After formulating the corresponding pastes (see below), they were dispersed in the planetary ball milling system for $24 \mathrm{~h}$ at $200 \mathrm{rpm}$. The pastes were finally obtained by concentrating the dispersed solution under vacuum at $40^{\circ} \mathrm{C}$ for $3 \mathrm{~h}$ to remove excess ethanol.

The FTO NP paste was formulated adding the listed materials, to the agate jar containing the agate beads in the following order: $1 \mathrm{~g}$ of $15 \mathrm{wt} \%$ polyvinyl butyral (PVB, molecular weight 40 000-70 $000 \mathrm{~g} / \mathrm{mol})$ in anhydrous ethanol, $100 \mu \mathrm{L}$ 2-butoxyethanol $(0.762 \mathrm{mmol}), 70 \mu \mathrm{L}$ 2-[2-(2methoxyethoxy)ethoxy]acetic acid (0.39 mmol), $15 \mu \mathrm{L}$ DISPERBYK-111, $0.968 \mathrm{~g}$ of $\alpha$-Terpineol with butyl carbitol acetate $(1: 1 \mathrm{w} / \mathrm{w}), 0.30 \mathrm{~g}$ of FTO NPs, and $30 \mathrm{~mL}$ anhydrous ethanol.

The ITO-50 NP paste was prepared by adding these materials to the agate jar with agate beads in the following order: $375 \mathrm{mg}$ of $<50 \mathrm{~nm}$ ITO powder, $1.6 \mathrm{~g}$ of $7.5 \%$ polyvinyl butyral (PVB, molecular weight $40000-70000 \mathrm{~g} / \mathrm{mol})$ in anhydrous ethanol, $0.375 \mathrm{~g}$ of $2 \%$ sodium docusate $(0.0169 \mathrm{mmol})$ inanhydrous ethanol, $70 \mu \mathrm{L}$ 2-[2-(2-methoxyethoxy)ethoxy]acetic acid $(0.39 \mathrm{mmol}), 15 \mu \mathrm{L}$ DISPERBYK-111, $1.06 \mathrm{~g}$ propylene glycol, $36 \mu \mathrm{L}$ glycerol (3\%), and $30 \mathrm{~mL}$ anhydrous ethanol.

\section{Deposition of $\mathrm{Fe}(\mathrm{x} \text {-tpy })_{2}$ complexes onto solid substrates}

Iron(II) complexes were deposited onto ITO-30, ITO-50, and FTO NP screen printed films on corresponding FTO/glass and ITO/glass substrates using an adapted version of the published procedure. ${ }^{1}$ In brief: substrates were submerged in a solution of trichloro(4(chloromethyl)phenyl)silane with dry hexane $(1: 100 \mathrm{v} / \mathrm{v})$ in an inert atmosphere. They were left standing for 20 minutes at room temperature, then rinsed in the inert atmosphere with hexane $(3 \times 15$ $\mathrm{mL}$ ) followed by anhydrous acetonitrile $(3 \times 15 \mathrm{~mL})$. They were then sonicated $(1 \times 15 \mathrm{~mL})$ per solvent for $5 \mathrm{~min}$. In an inert atmosphere, the silane-templated substrates were submerged in a pressure tube with $0.4 \mathrm{mM}$ solution of the desired $\mathrm{Fe}\left(\mathrm{x}\right.$-tpy) ${ }_{2}$ complex (where $\mathrm{x}$ is $\mathrm{s}, \mathrm{d}$, or $\mathrm{t}$ ), and then heated for 5 days in the dark at $85^{\circ} \mathrm{C}$. They were brought to room temperature, then exposed to air upon rinsing 3 $\mathrm{x}$ with acetonitrile, and then hexane. They were sonicated $1 \mathrm{x}$ per solvent for $5 \mathrm{~min}$. 


\section{Crystal Structure}

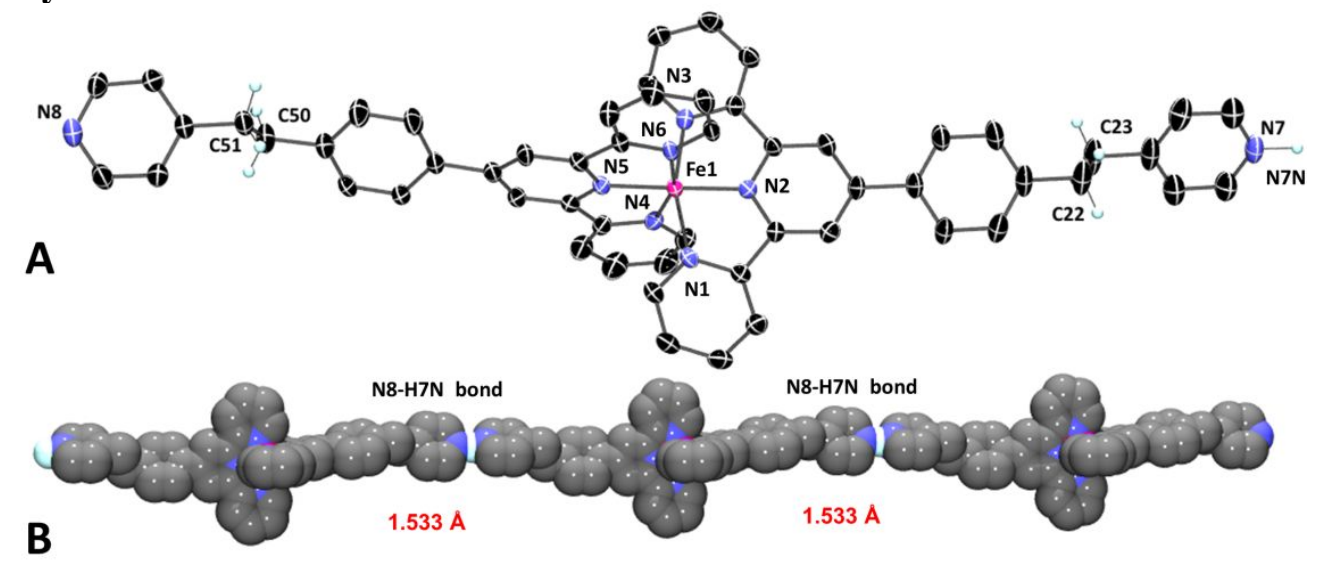

Figure S1: A) Crystallographically determined structure of mono-protonated version of complex $\left[\mathrm{Fe}(\mathrm{s} \text {-tpy })_{2}\right]\left(\mathrm{BF}_{4}\right)_{2}$ with thermal ellipsoids set at 50\%. Hydrogen atoms (except $\mathrm{CH}_{2}=\mathrm{CH}_{2}$ and $\mathrm{N}-\mathrm{H}$ hydrogens) and $\mathrm{BF}_{4}$ counter anions are omitted for clarity. Selected bond lengths $(\AA)$ and angles $\left(^{\circ}\right)$ : $\mathrm{Fe}(1)-\mathrm{N}(1)$ 1.968(2), $\mathrm{Fe}(1)-\mathrm{N}(2) 1.874(2), \mathrm{Fe}(1)-\mathrm{N}(3) 1.965(2), \mathrm{Fe}(1)-$ $\mathrm{N}(4)$ 1.967(2), $\mathrm{Fe}(1)-\mathrm{N}(5)$ 1.877(2), $\mathrm{Fe}(1)-\mathrm{N}(6)$ 1.978(2), C(22)-C(23) 1.509(5), C(50)-C(52) 1.498(4), N(7)-C(H7) 1.13(5), $\mathrm{N}(5)-\mathrm{Fe}(1)-\mathrm{N}(2)$ 178.79(10), N(3)-Fe(1)-N(4) 93.11(10), N(6)-Fe(1)-N(1) 95.00(16). (See Table S1 for crystal

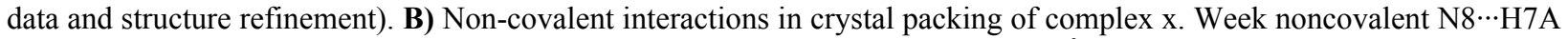
interactions play important role in packing of the complex. $\mathrm{N} \cdots \mathrm{H}$ distance is $1.533 \AA$ that is significantly lower the sum of van der Waals radii for individual atoms $\mathrm{H}$ and $\mathrm{N}(1.20+1.55=2.75 \AA)$.

Table S1. Crystal data and structure refinement for d17144_a asq.

Identification code

Empirical formula

Formula weight

Temperature

Wavelength

Crystal system

Space group

Unit cell dimensions

Volume

Z

Density (calculated)

Absorption coefficient

$\mathrm{F}(000)$

Crystal size

Theta range for data collection

Index ranges

Reflections collected

Independent reflections

Completeness to theta $=67.501^{\circ}$

Absorption correction

Max. and min. transmission

Refinement method

Data / restraints / parameters

Goodness-of-fit on $\mathrm{F}^{2}$

Final R indices [I $>2 \operatorname{sigma}(\mathrm{I})]$

$\mathrm{R}$ indices (all data)

Extinction coefficient

Largest diff. peak and hole d17144_a_sq

C60 H54 B2 F8 Fe N8 O

1059.47

$150(2) \mathrm{K}$

$1.54178 \AA$

Triclinic

P-1

$\mathrm{a}=9.2517(3) \AA$

$\alpha=110.056(2)^{\circ}$.

$\mathrm{b}=18.0554(5) \AA$

$\beta=100.932(2)^{\circ}$.

$\mathrm{c}=18.3197(5) \AA$

2736.64(14) $\AA^{3}$

2

$1.286 \mathrm{Mg} / \mathrm{m}^{3}$

$2.815 \mathrm{~mm}^{-1}$

1090

$0.430 \times 0.100 \times 0.030 \mathrm{~mm}^{3}$

2.662 to $67.501^{\circ}$.

$-10<=\mathrm{h}<=11,-21<=\mathrm{k}<=21,-21<=1<=21$

113100

$9691[\mathrm{R}(\mathrm{int})=0.0956]$

$98.3 \%$

Semi-empirical from equivalents

0.7530 and 0.5726

Full-matrix least-squares on $\mathrm{F}^{2}$

$9691 / 58 / 717$

1.056

$\mathrm{R} 1=0.0572, \mathrm{wR} 2=0.1429$

$\mathrm{R} 1=0.0763, \mathrm{wR} 2=0.1563$

$\mathrm{n} / \mathrm{a}$

0.358 and -0.583 e. $\AA^{-3}$ 

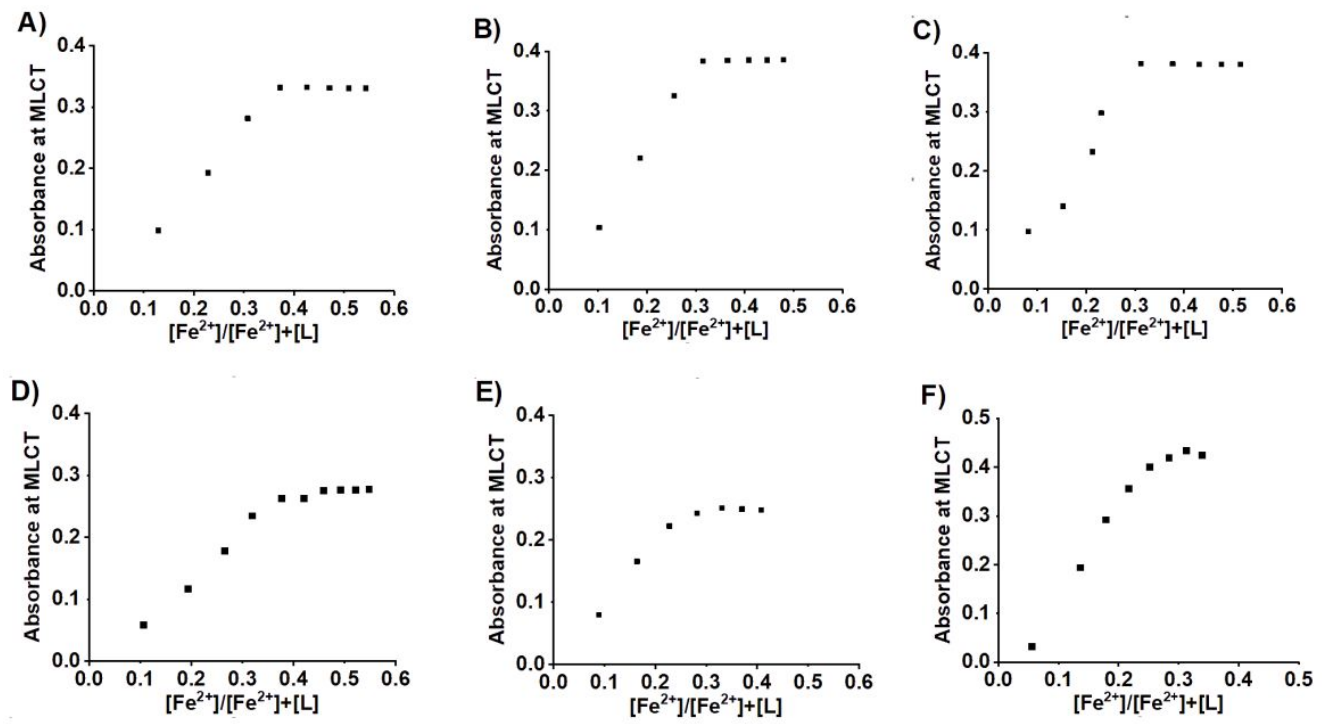

Figure S2: Jobs plots in $\mathrm{CH}_{3} \mathrm{CN}$ : A) $\left.\left[\mathrm{Fe}(\mathrm{s} \text {-tpy })_{2}\left(\mathrm{BF}_{4}\right)_{2}\right], \mathbf{B}\right)\left[\mathrm{Fe}(\mathrm{d}-\mathrm{tpy})_{2}\left(\mathrm{BF}_{4}\right)_{2}\right]$, and $\left.\left.\mathbf{C}\right)\left[\mathrm{Fe}(\mathrm{t}-\mathrm{tpy})_{2}\left(\mathrm{BF}_{4}\right)_{2}\right], \mathbf{D}\right)\left[\mathrm{Fe}\left(\mathrm{CH}_{3^{-}}\right.\right.$ s-tpy $\left.\left.)_{2}(\mathrm{I})\left(\mathrm{BF}_{4}\right)_{2}\right], \mathbf{E}\right)\left[\mathrm{Fe}\left(\mathrm{CH}_{3} \text {-d-tpy }\right)_{2}(\mathrm{I})\left(\mathrm{BF}_{4}\right)_{2}\right]$, and $\left.\mathbf{F}\right)\left[\mathrm{Fe}\left(\mathrm{CH}_{3} \text {-t-tpy }\right)_{2}(\mathrm{I})\left(\mathrm{BF}_{4}\right)_{2}\right]$.

\section{Characterization of FTO NPs}

X-Ray diffraction (XRD) pattern for the FTO NPs matches the literature spectrum, containing characteristic peaks for $\mathrm{SnO}_{2}$ but no detectable peaks for fluorine. ${ }^{2}$ The average size of the NPs was calculated using the XRD pattern and the Scherrer equation (Eq. S1) where $\tau$ gives the average particle size, $\lambda$ is the $\mathrm{X}$-ray source wavelength, $\beta$ is the width of the peak at half-height, and $\theta$ is the Bragg angle.

$$
\tau=\frac{0.9 \lambda}{\beta \cos \theta}
$$

The average size was $19.57 \mathrm{~nm}$, which is also in good correlation with the literature value. ${ }^{2}$
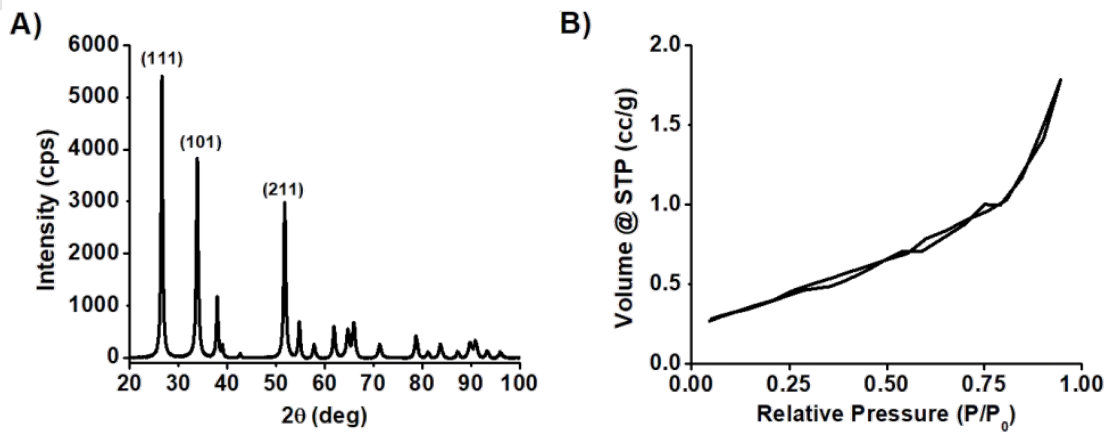

Figure S3: A) XRD patterns of FTO NPs, B) BET isotherm for FTO NPs.

The Brunauer-Emmett-Teller (BET) isotherm plot for the FTO NPs gave the average pore radius of $3.50 \mathrm{~nm}$ with surface area $17.62 \mathrm{~m}^{2} / \mathrm{g}$.

Cyclic voltammetry (CV) was measured for the FTO NPs on the FTO-glass substrate (Figure S3A) in the operating range of -0.13 to $1.7 \mathrm{~V}$ vs. $\mathrm{Fc} / \mathrm{Fc}^{+}$. In the region above $0.75 \mathrm{~V} \mathrm{vs}$. $\mathrm{Fc} / \mathrm{Fc}^{+}$, slight 
material decomposition was observed from cycle 100 to 200, and this slowed through additional cycling. Almost no change was observed between cycles 300 and 400. A small peak is visible for the reference electrode $\mathrm{AgNO}_{3}$ at $0.04 \mathrm{~V}$ vs. $\mathrm{Fc} / \mathrm{Fc}^{+}$. The material experienced capacitance when cycling toward negative potentials beyond $1.0 \mathrm{~V}$ vs. $\mathrm{Fc} / \mathrm{Fc}^{+}$, and impedance was thereby measured at $-0.02 \mathrm{~V}, 0.60 \mathrm{~V}$ and $1.17 \mathrm{~V}$ vs. $\mathrm{Fc} / \mathrm{Fc}^{+}$. While the material experienced resistance near the region of $1.17 \mathrm{~V}$ vs. $\mathrm{Fc} / \mathrm{Fc}^{+}$, capacitive behaviors were observed near $0 \mathrm{~V}$ vs. $\mathrm{Fc} / \mathrm{Fc}^{+}$. An increase in capacitance is observed for more negative potentials.

A)

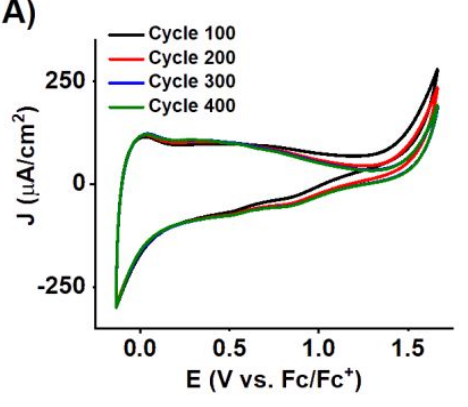

B)

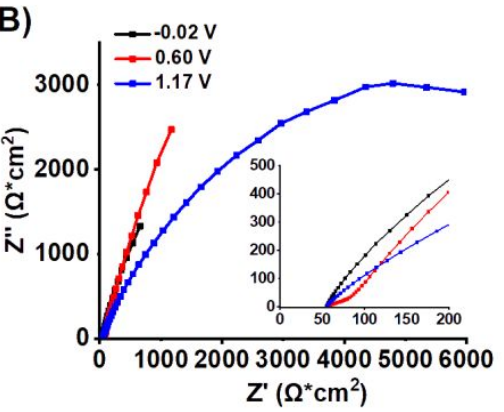

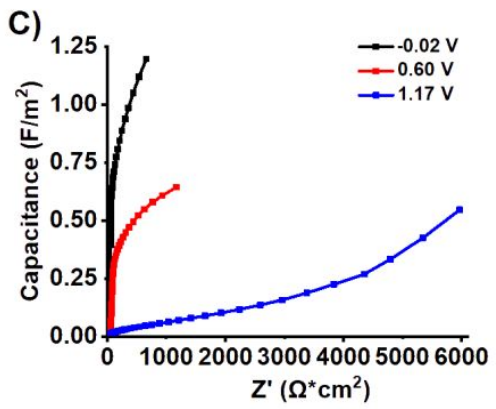

Figure S4: A) Durability at $100 \mathrm{mV} / \mathrm{s}$, B) Nyquist plot, and C) capacitance plot for blank FTO NPs screen-printed film on FTO/glass substrate (3 electrode cell, 0.1M TBAHFP/MeCN).

\section{Cyclic Voltammetry of EC materials}

Linear regression of peak current $\left(i_{p}\right)$ versus sweep rate $(v)$ allows for calculation of surface coverage $(\Gamma)$ with respect to the specific ECM surface area $\left(A_{S U R}\right)$ using equation $\mathbf{S 2} .^{3}$

$$
i_{p}=\frac{n^{2} F^{2}}{4 R T} v A_{S U R} \Gamma
$$

To effectively compare the different substrates, this data was normalized to the BET SA of the corresponding NPs: $10.2 \mathrm{~m}^{2} \mathrm{~g}^{-1}$ for ITO-30, ${ }^{4} 30 \mathrm{~m}^{2} \mathrm{~g}^{-1}$ for ITO-50, and $17.62 \mathrm{~m}^{2} \mathrm{~g}^{-1}$ for FTO. The surface coverage of redox active complexes applying BET SA is summarized in Table 2 (main text). 


\section{CV of ITO-30 NPs on ITO/Glass Substrate}
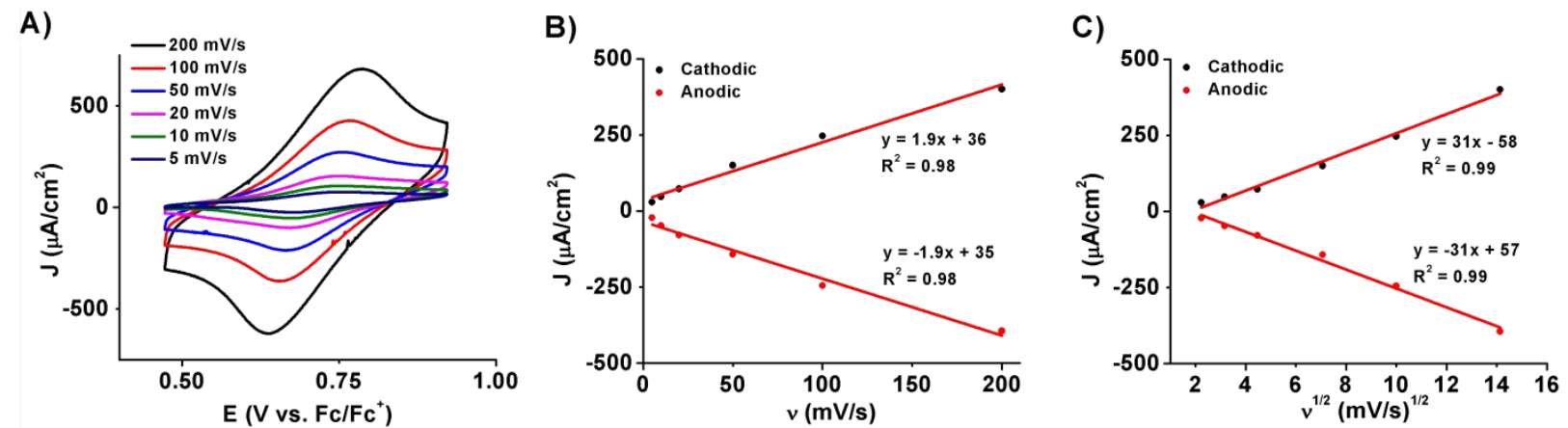

Figure S5: CVs of [Fe(s-tpy) $)_{2} @$ ITO-30 NP on ITO /glass substrate: A) Full CVs, B) relationship between current density and sweep rates, C) relationship between current density and root of the sweep rate (3 electrode cell, $0.1 \mathrm{M}$ TBAHFP/MeCN).
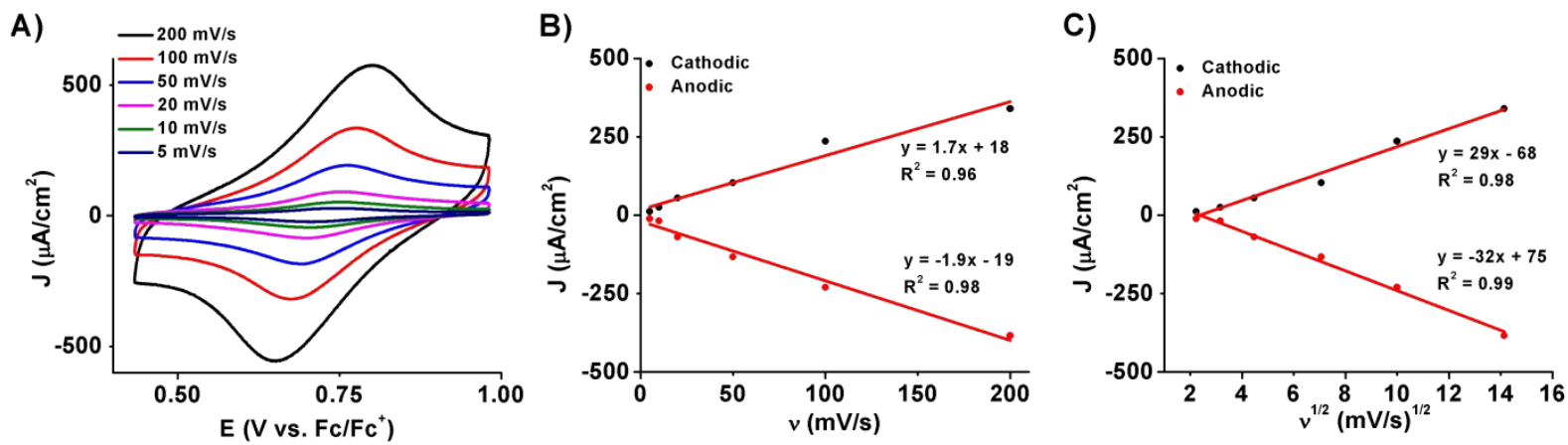

Figure S6: CVs of [Fe(d-tpy) $)_{2}$ @ ITO-30 NP on ITO /glass substrate: A) Full CVs, B) relationship between current density and sweep rates, C) relationship between current density and root of the sweep rate (3 electrode cell, $0.1 \mathrm{M}$ TBAHFP/MeCN).
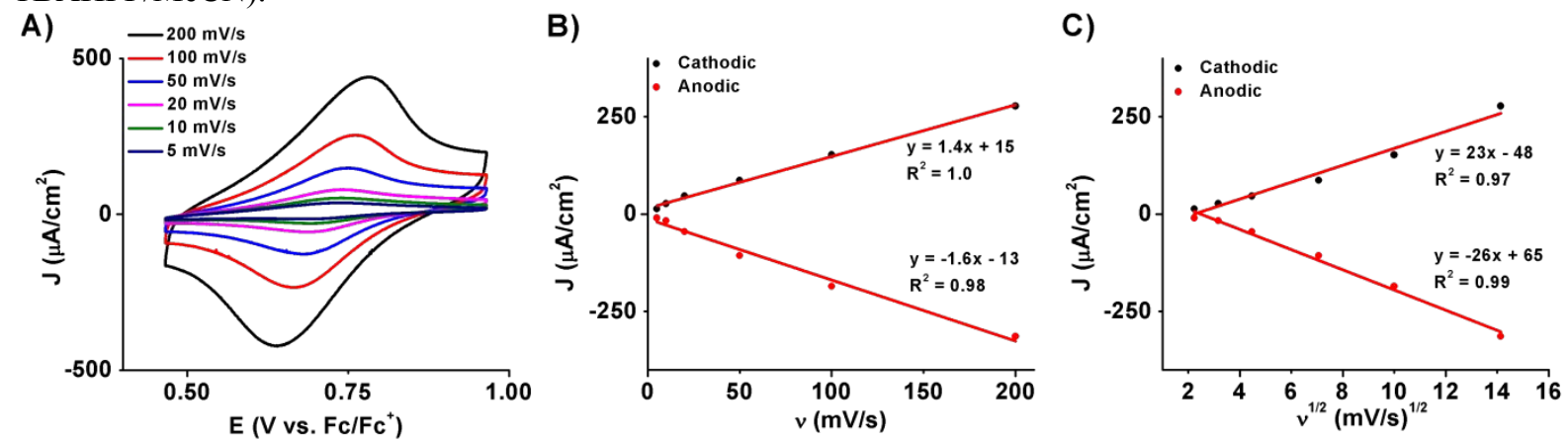

Figure S7: CVs of [Fe(t-tpy) $)_{2} @$ ITO-30 NP on ITO /glass substrate: A) Full CVs, B) relationship between current density and sweep rates, $\mathbf{C}$ ) relationship between current density and root of the sweep rate (3 electrode cell, $0.1 \mathrm{M}$ TBAHFP/MeCN). 


\section{CV of ITO-50 NPs on ITO/Glass Substrate}

A)

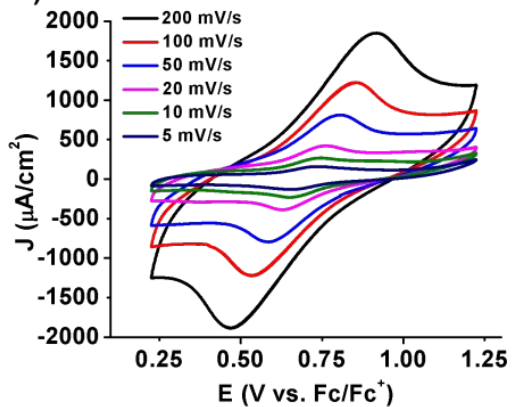

B)

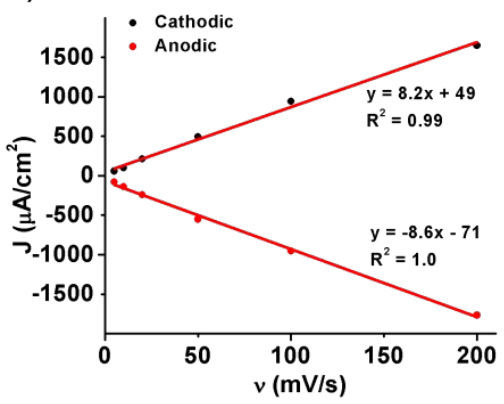

C)

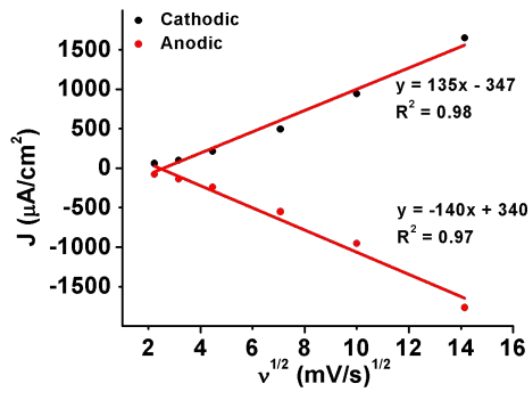

Figure S8: CVs of [Fe(s-tpy) 2 @ITO-50/ITO/glass substrate: A) Full CVs, B) relationship between current density and sweep rates, C) relationship between current density and root of the sweep rate (3 electrode cell, $0.1 \mathrm{M}$ TBAHFP/MeCN).
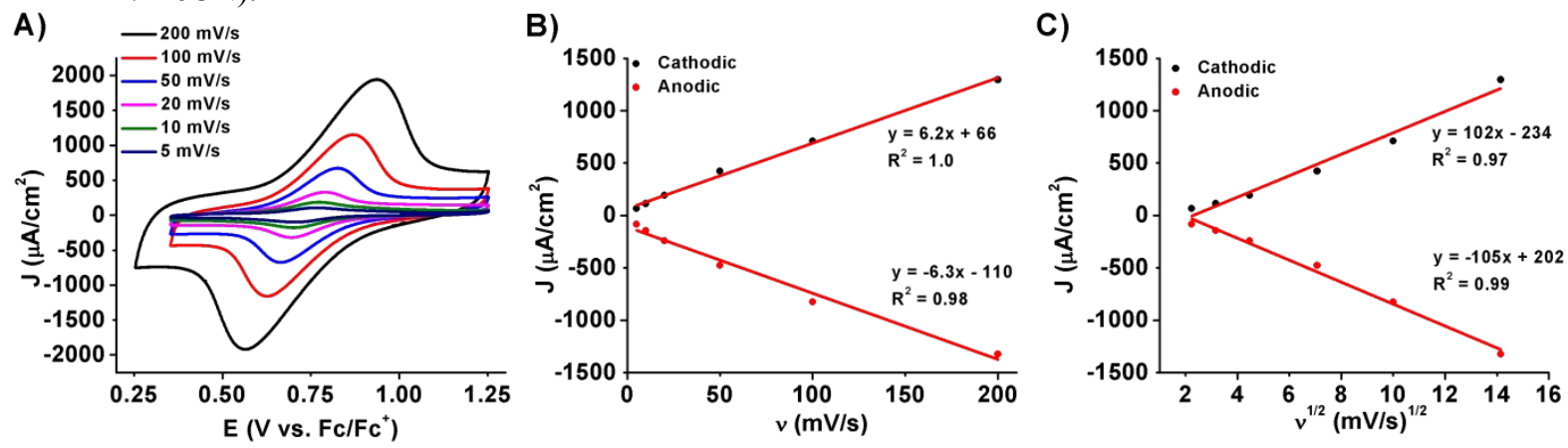

Figure S9: CVs of [Fe(d-tpy) 2 @ @ITO-50/ITO/glass substrate: A) Full CVs, B) relationship between current density and sweep rates, C) relationship between current density and root of the sweep rate (3 electrode cell, $0.1 \mathrm{M}$ TBAHFP/MeCN).

For CVs of [Fe(t-tpy) 2 @ ITO-50/ITO/glass substrate: full CVs, relationship between current density and sweep rates, and relationship between current density and root of the sweep rate ( 3 electrode cell, $0.1 \mathrm{M}$ TBAHFP/MeCN) see Figure 3 B,C,D in the main text.

CV of FTO NPs on ITO/Glass Substrate
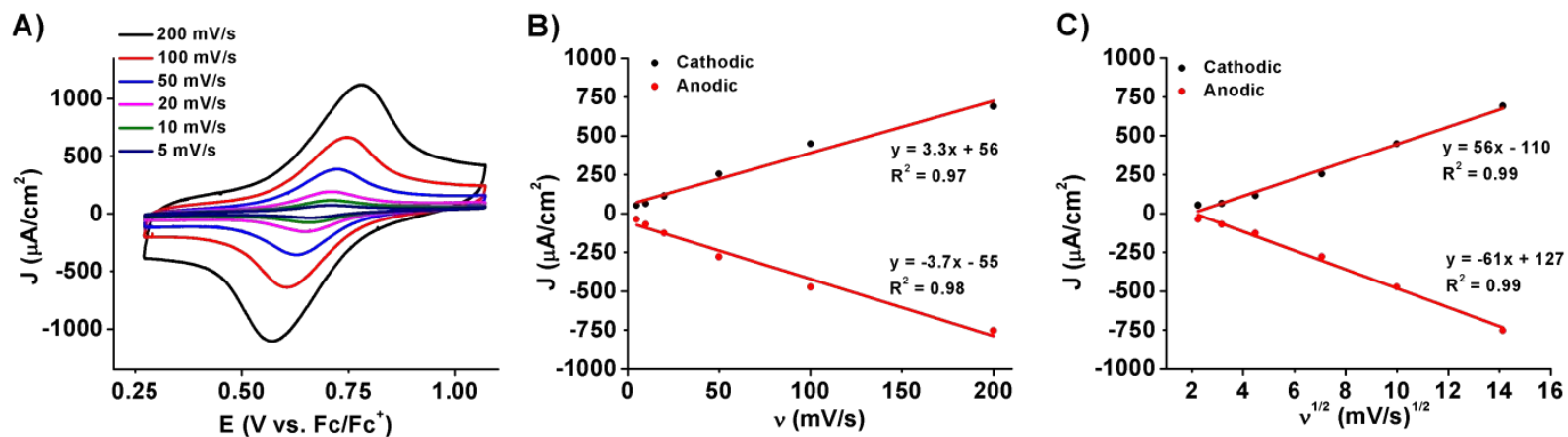

Figure S10: CVs of [Fe(s-tpy) $)_{2} @$ FTO/ITO/glass substrate: A) Full CVs, B) relationship between current density and sweep rates, C) relationship between current density and root of the sweep rate (3 electrode cell, $0.1 \mathrm{M}$ TBAHFP/MeCN). 

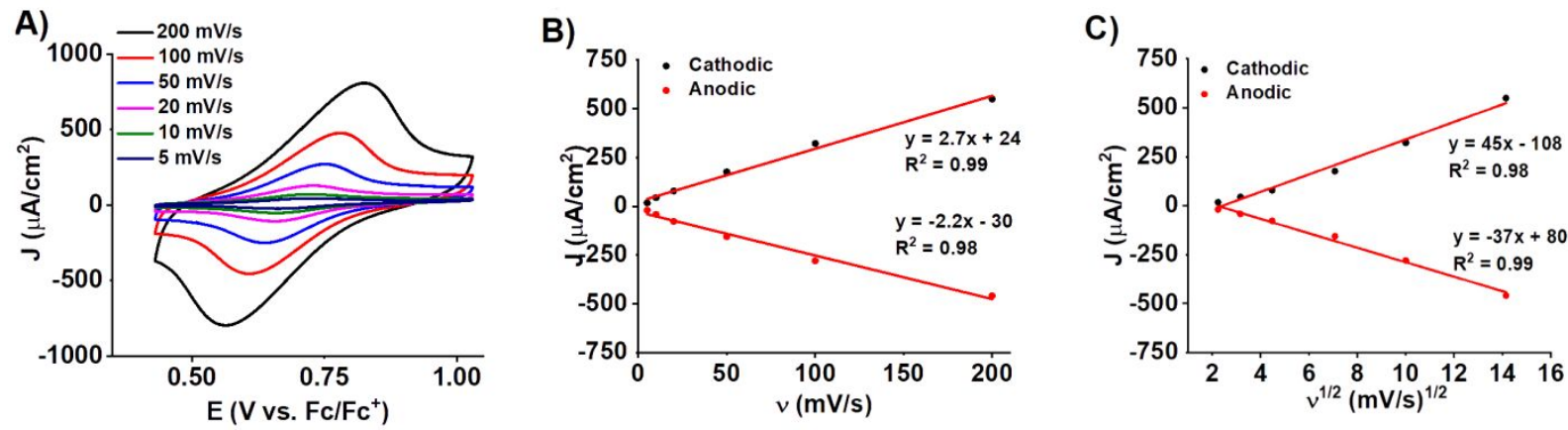

Figure S11: CVs of [Fe(d-tpy) $)_{2} @$ FTO/ITO/glass substrate: A) Full CVs, B) relationship between current density and sweep rates, C) relationship between current density and root of the sweep rate (3 electrode cell, $0.1 \mathrm{M}$ TBAHFP/MeCN).
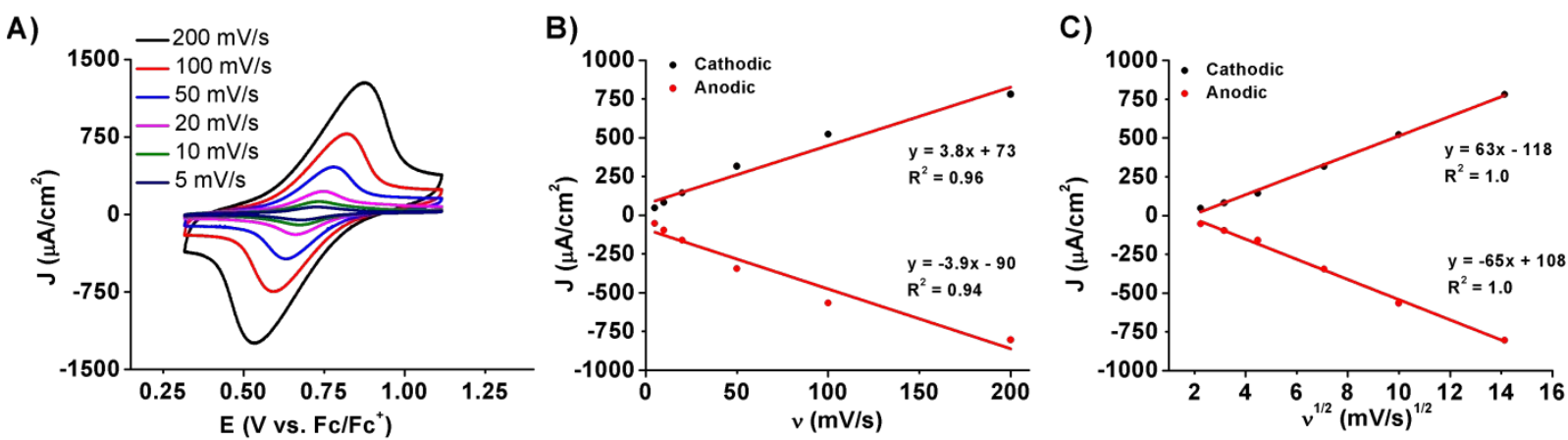

Figure S12: CVs of [Fe(t-tpy $)_{2}$ @ FTO/ITO/glass substrate: A) Full CVs, B) relationship between current density and sweep rates, C) relationship between current density and root of the sweep rate (3 electrode cell, $0.1 \mathrm{M}$ TBAHFP/MeCN).

\section{CV of FTO NPs on FTO/Glass Substrate}

A)

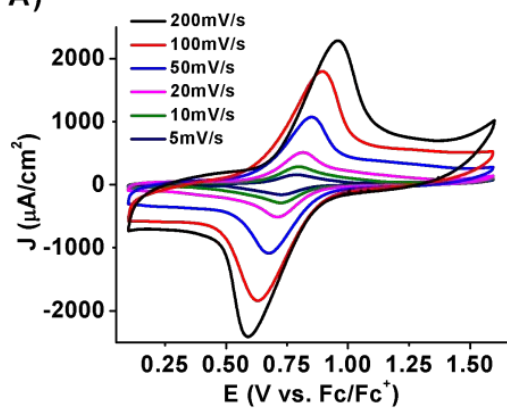

B)

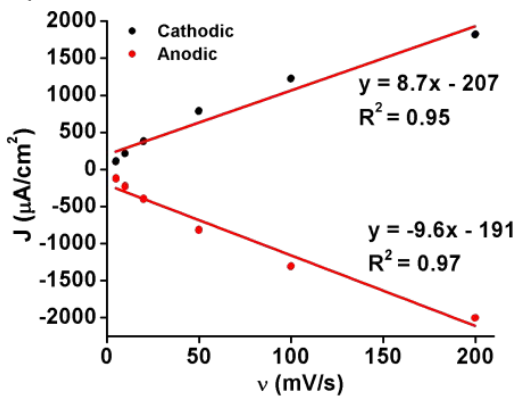

C)

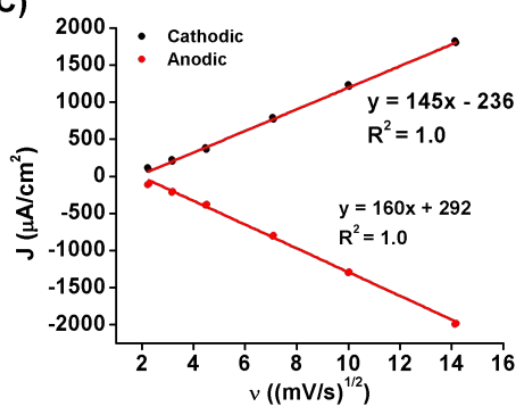

Figure S13: CVs of [Fe(s-tpy) $)_{2} @ \mathrm{FTO} / \mathrm{FTO} /$ glass substrate: A) Full CVs, B) relationship between current density and sweep rates, C) relationship between current density and root of the sweep rate (3 electrode cell, $0.1 \mathrm{M}$ TBAHFP/MeCN). 

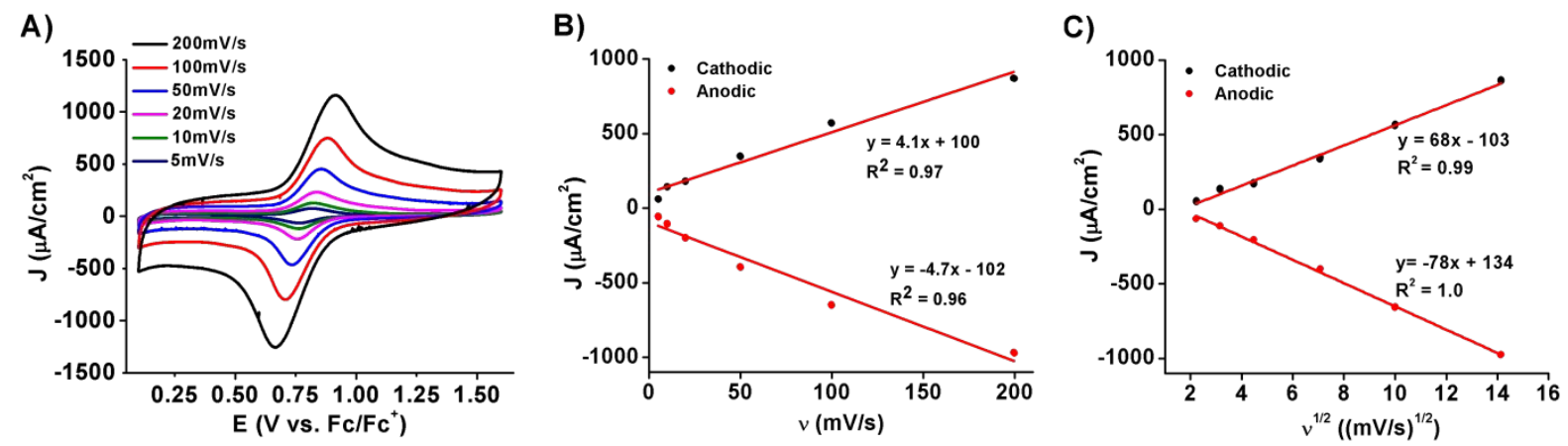

Figure S14: CVs of [Fe(d-tpy $\left.)_{2}\right]$ @FTO/FTO/glass substrate: A) Full CVs, B) relationship between current density and sweep rates, C) relationship between current density and root of the sweep rate (3 electrode cell, $0.1 \mathrm{M}$ TBAHFP/MeCN).

For CVs of [Fe(t-tpy $\left.)_{2}\right] @$ FTO/FTO/glass substrate: full CVs, linear relationship between current density and sweep rates, and linear relationship between current density and root of the sweep rate (3 electrode cell, $0.1 \mathrm{M}$ TBAHFP/MeCN) see Figure 3 E, F, G in the main text.

\section{Laviron Kinetics}
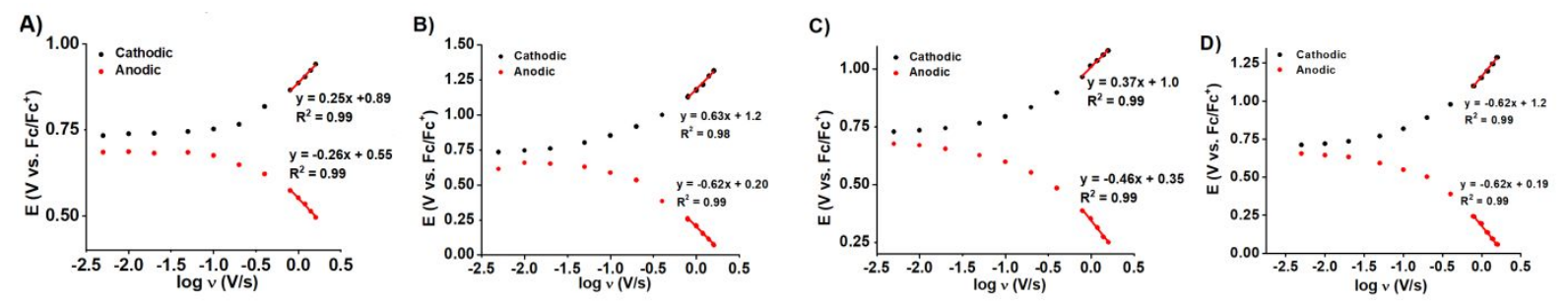

Figure S15: Laviron plot for [Fe(s-tpy) 2 ] on A) ITO-30 on ITO/glass, B) ITO-50 on ITO/glass, C) FTO on ITO/glass, and D) FTO on FTO/glass.
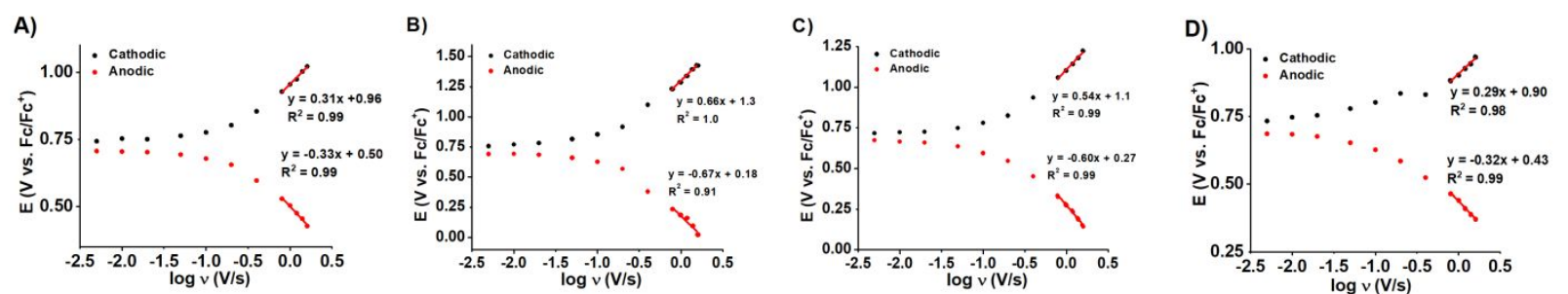

Figure S16: Laviron plot for [Fe(d-tpy $)_{2}$ ] on A) ITO-30 on ITO/glass, B) ITO-50 on ITO/glass, C) FTO on ITO/glass, and D) FTO on FTO/glass.

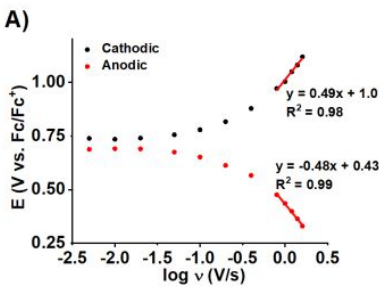

B)

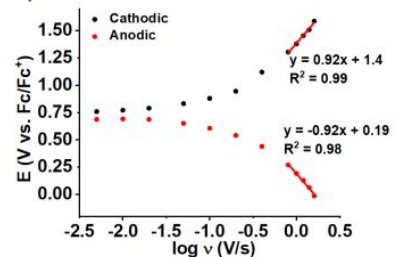

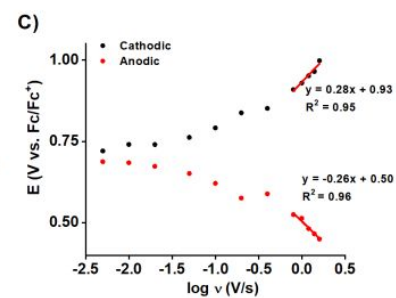

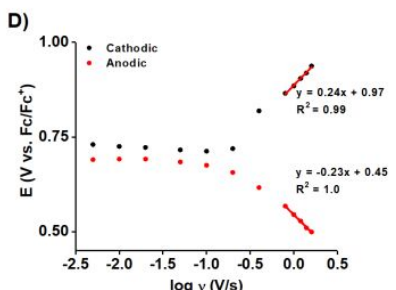

Figure S17: Laviron plot for [Fe(t-tpy $)_{2}$ ] on A) ITO-30 on ITO/glass, B) ITO-50 on ITO/glass, C) FTO on ITO/glass, and D) FTO on FTO/glass. 
Spectroelectrochemical (SEC) properties.

i)

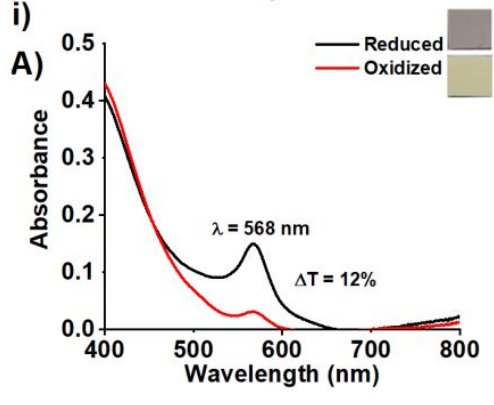

B)

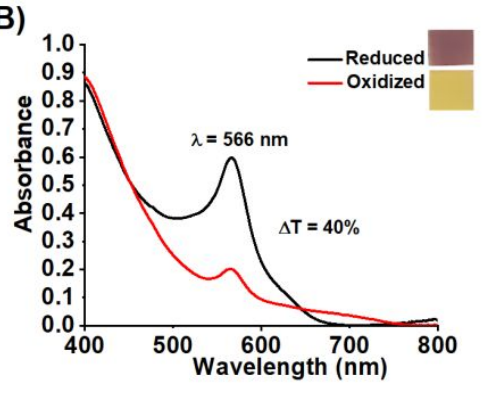

C)

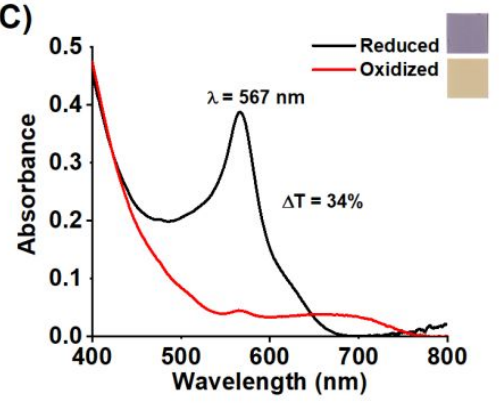

D)

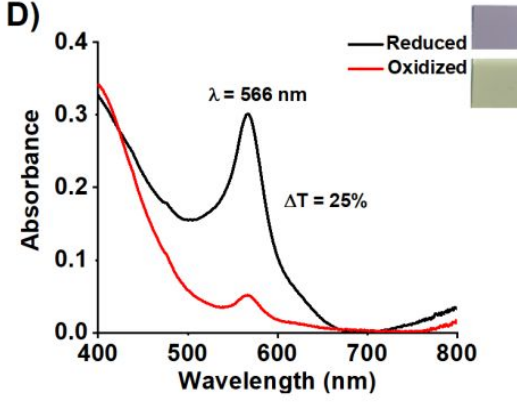

ii)
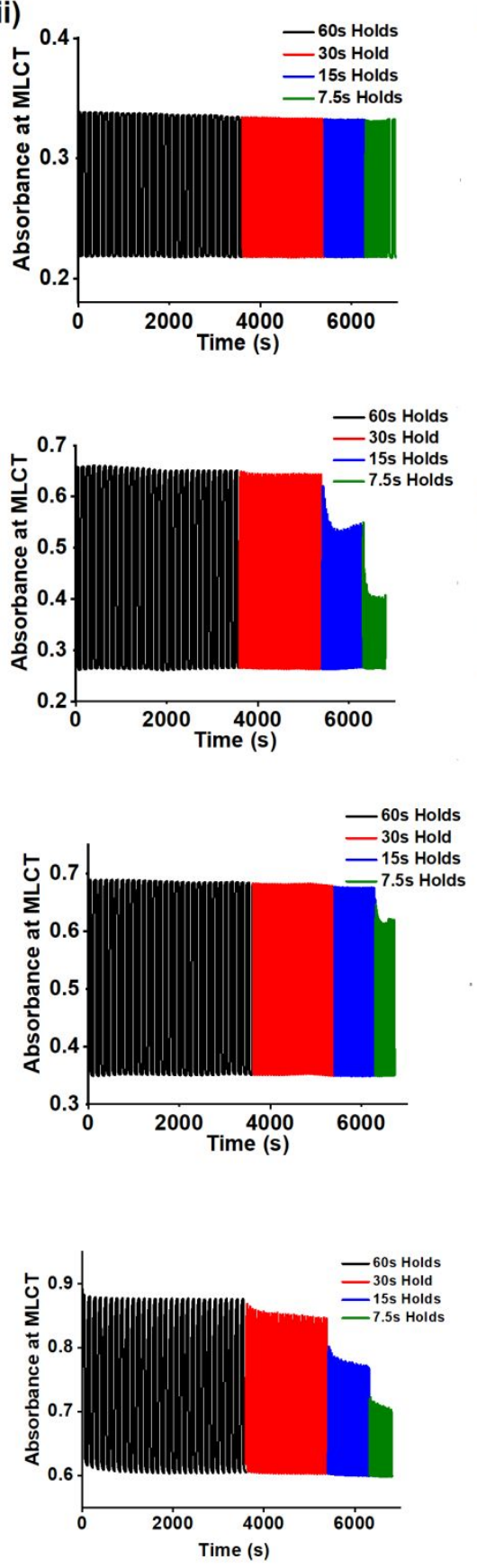
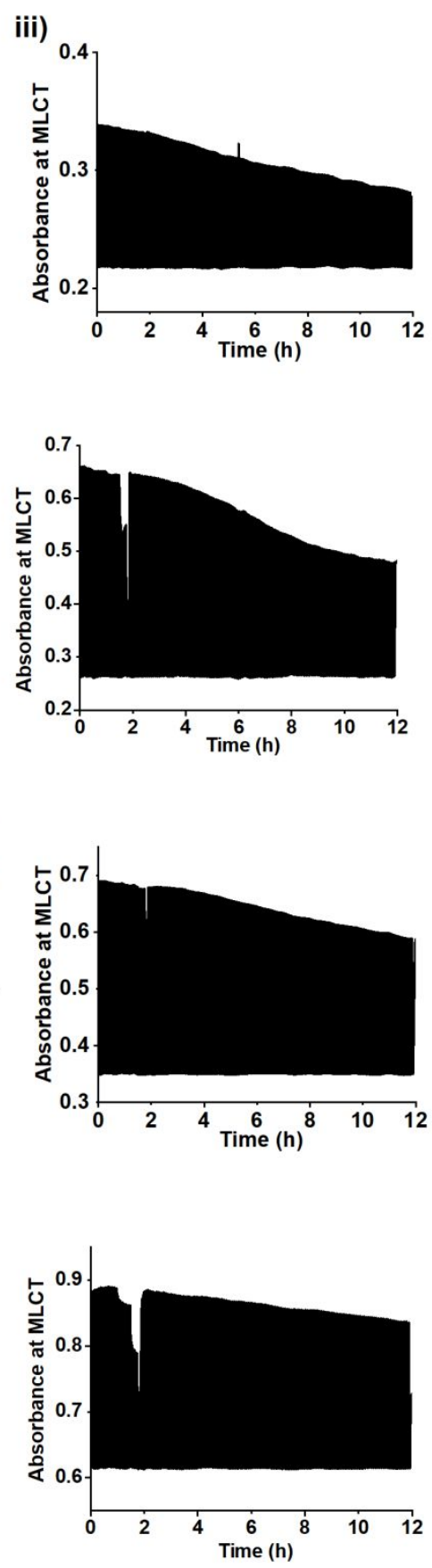

Figure S18: SEC cycling between $-1 \mathrm{~V}$ to $+3 \mathrm{~V}$ for $\left[\mathrm{Fe}(\mathrm{s}-\mathrm{tpy})_{2}\right]$ : i) $\mathrm{UV}-\mathrm{Vis}$, ii) different speeds of cycling down (30 cycles/speed), and iii) long term durability $60 \mathrm{~s} /$ hold, where the complex is anchored on A) ITO-30/ITO/glass, B) ITO-50/ITO/glass, C) FTO/ITO/glass, and D) FTO/FTO/glass (2 electrode cell, $\mathrm{Li}^{+}$electrolyte). 
i)

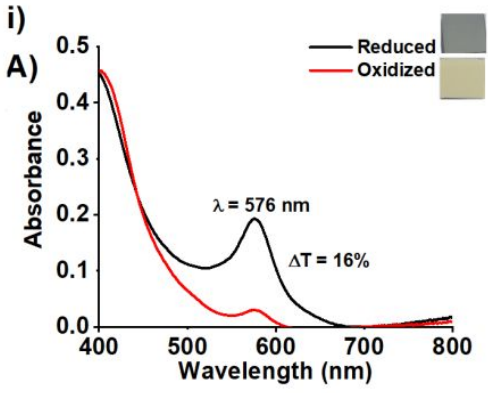

B)

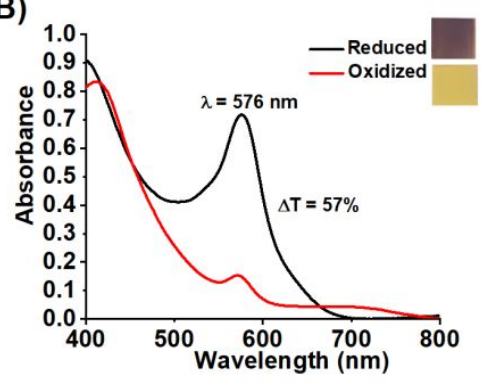

C)

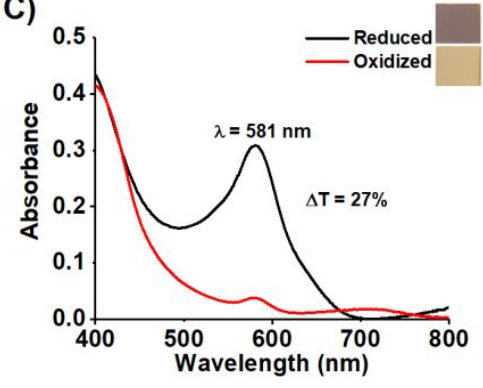

D)

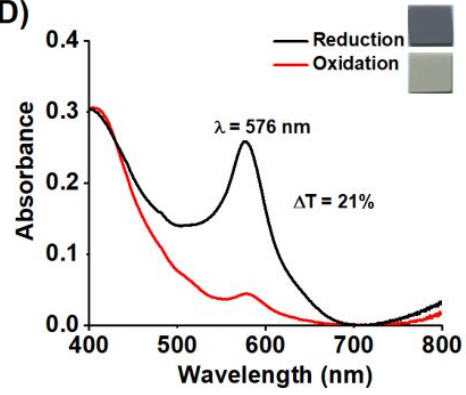

ii)
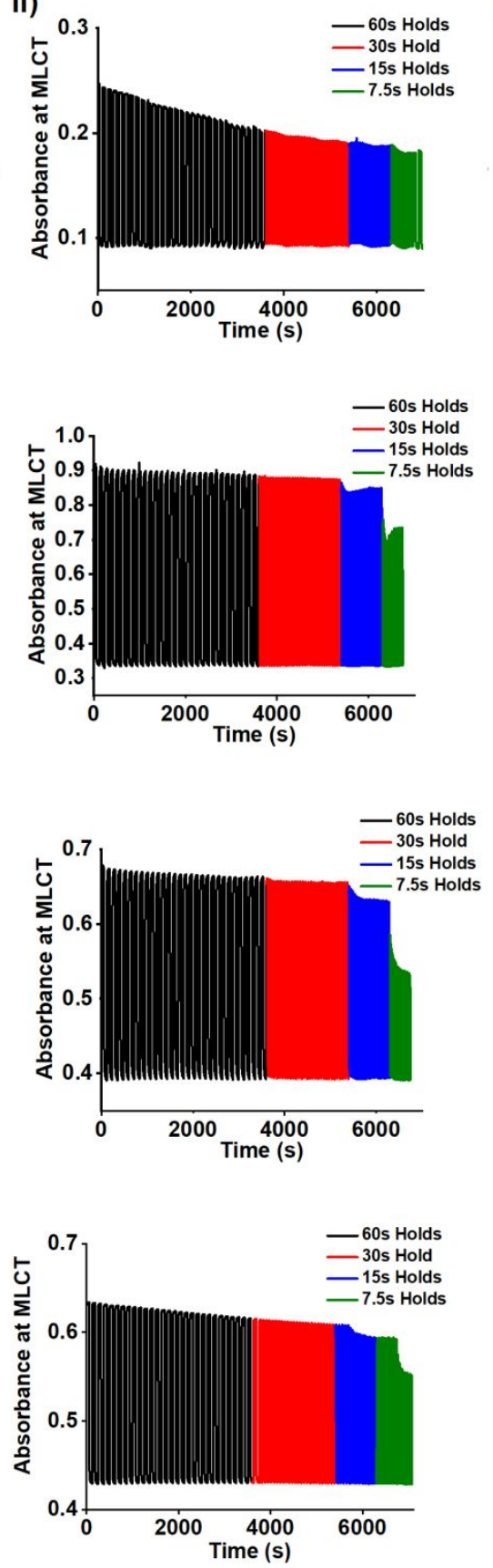

iii)
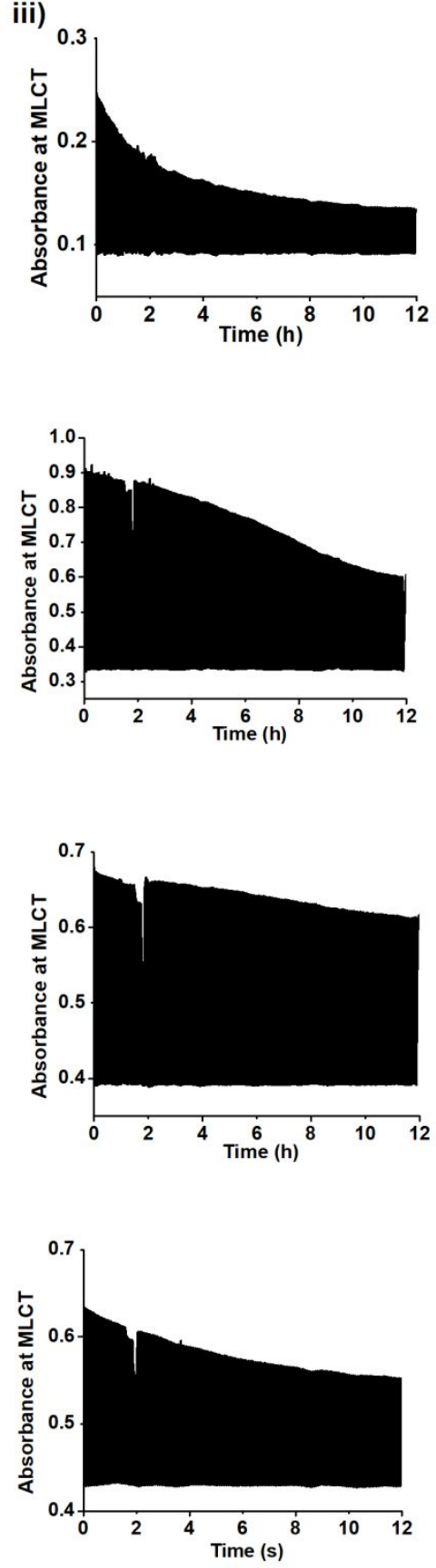

Figure S19: SEC sycling between $-1 \mathrm{~V}$ to $+3 \mathrm{~V}$ for $\left[\mathrm{Fe}(\mathrm{d}-\mathrm{tpy})_{2}\right]$ : i) $\mathrm{UV}-\mathrm{Vis}$, ii) different speeds of cycling down (30 cycles/speed), and iii) long term durability $60 \mathrm{~s} /$ hold, where the complex is anchored on A) ITO-30/ITO/glass, B) ITO-50/ITO/glass, C) FTO/ITO/glass, and D) FTO/FTO/glass (2 electrode cell, $\mathrm{Li}^{+}$electrolyte). 

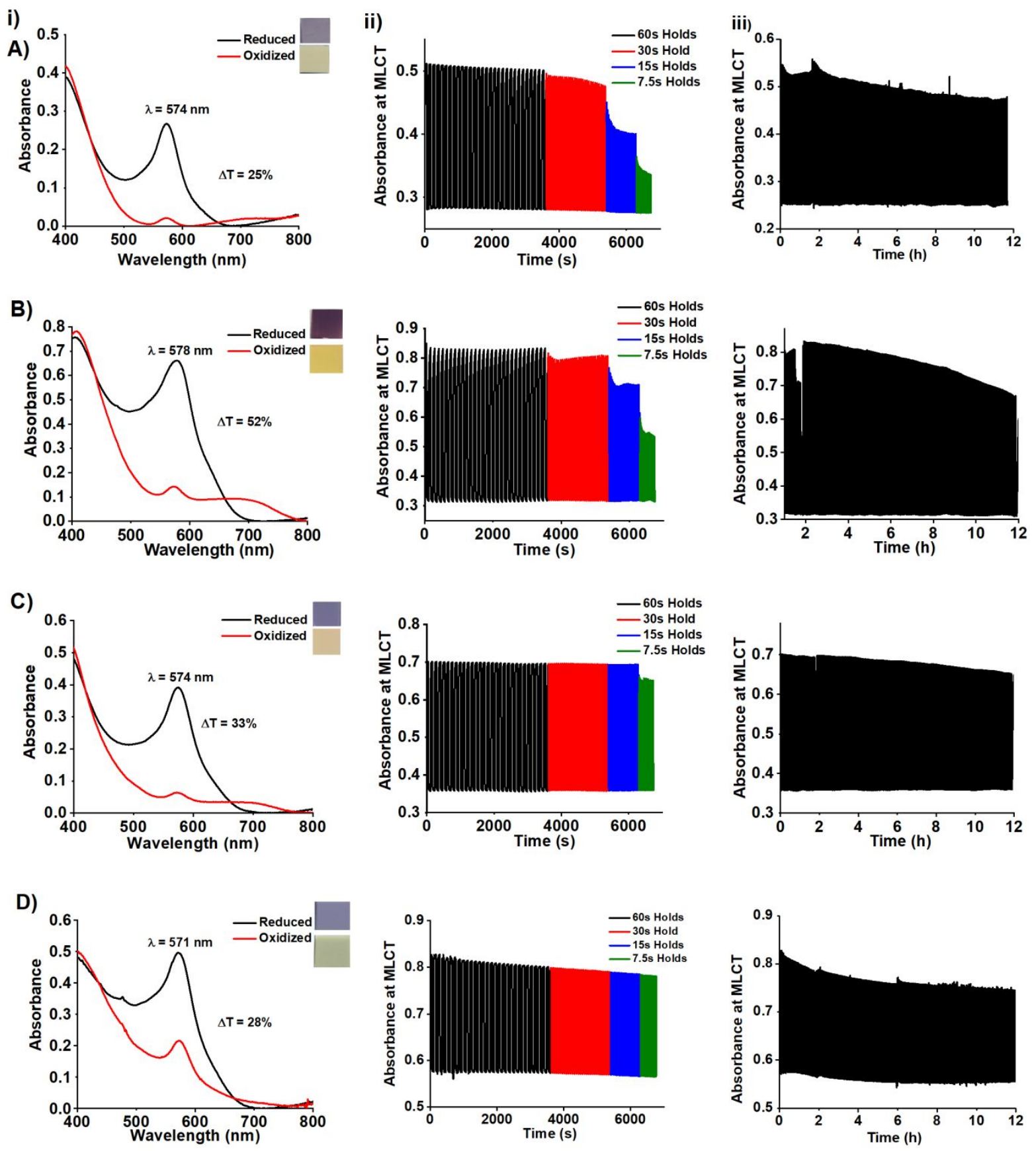

Figure S20: SEC cycling between $-1 \mathrm{~V}$ to $+3 \mathrm{~V}$ for $\left[\mathrm{Fe}(\mathrm{t}-\mathrm{tpy})_{2}\right]$ : i) $\mathrm{UV}-\mathrm{Vis}$, ii) different speeds of cycling down (30 cycles/speed), and iii) long term durability 60 s/hold, where A) ITO-30 on ITO/glass, B) ITO-50 on ITO/glass, C) FTO on ITO/glass, and D) FTO on FTO/glass (2 electrode cell, $\mathrm{Li}^{+}$electrolyte). 


\section{Coloration Efficiency}

It was demonstrated for electrochemical supercapacitors that specific capacitance depends on the accessibility of the surface area by the electrolyte. The relationship has an optimal ratio for the surface area to electrolyte ion radius, thus explains the discrepancies between ITO-30 NPs and the ITO-50. ${ }^{5}$
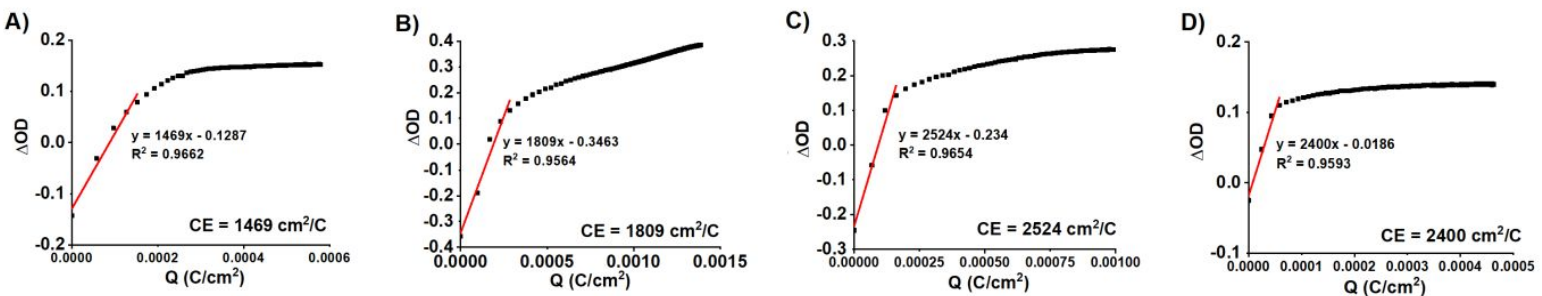

Figure S21: Coloration efficiencies for $\left[\mathrm{Fe}(\mathrm{s}-\mathrm{tpy})_{2}\right]$ on A) ITO-30/ITO/glass, FTO/ITO/glass, and D) FTO/FTO/glass (solid state, -1V).
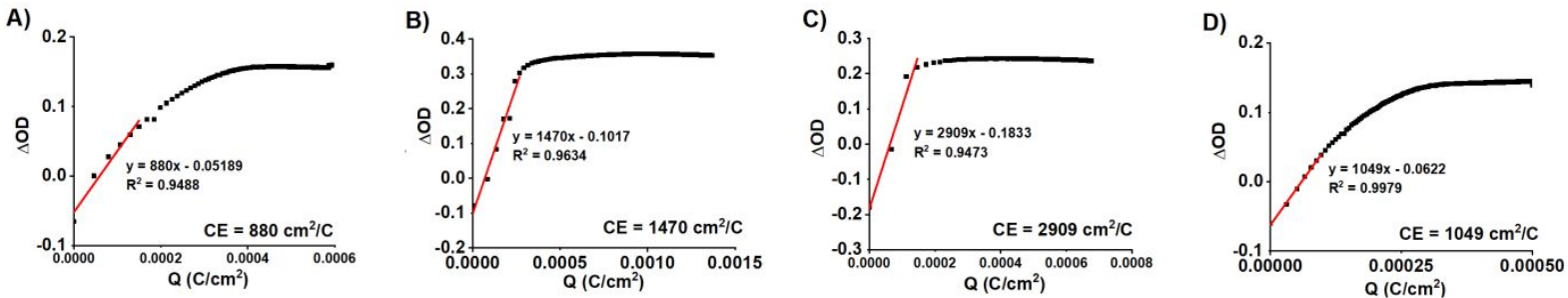

Figure S22: Coloration efficiencies for $\left[\mathrm{Fe}(\mathrm{d}-\mathrm{tpy})_{2}\right]$ on A) ITO-30, B) ITO-50, C) FTO on ITO/glass, and D) FTO on FTO/glass (solid state, $-1 \mathrm{~V}$ ).
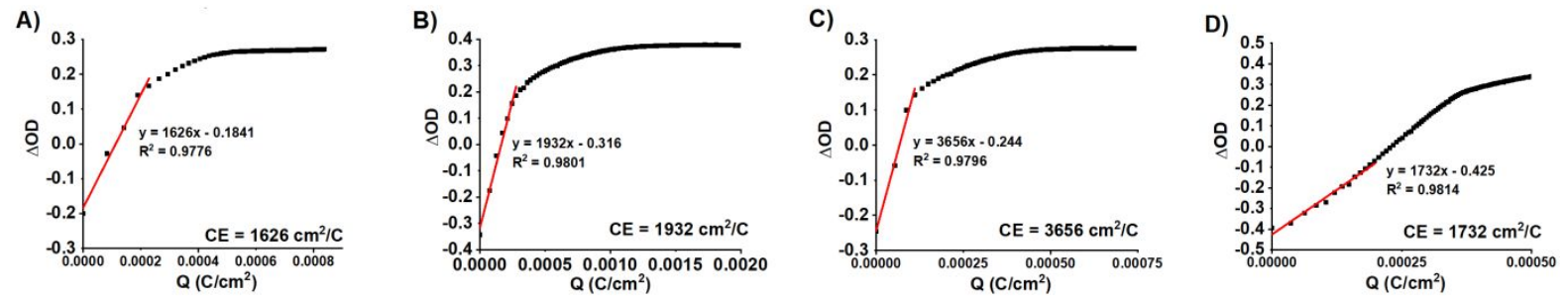

Figure S23: Coloration efficiencies for [Fe(t-tpy $\left.)_{2}\right]$ on A) ITO-30, B) ITO-50, C) FTO on ITO/glass, and D) FTO on FTO/glass (solid state, $-1 \mathrm{~V}$ ).

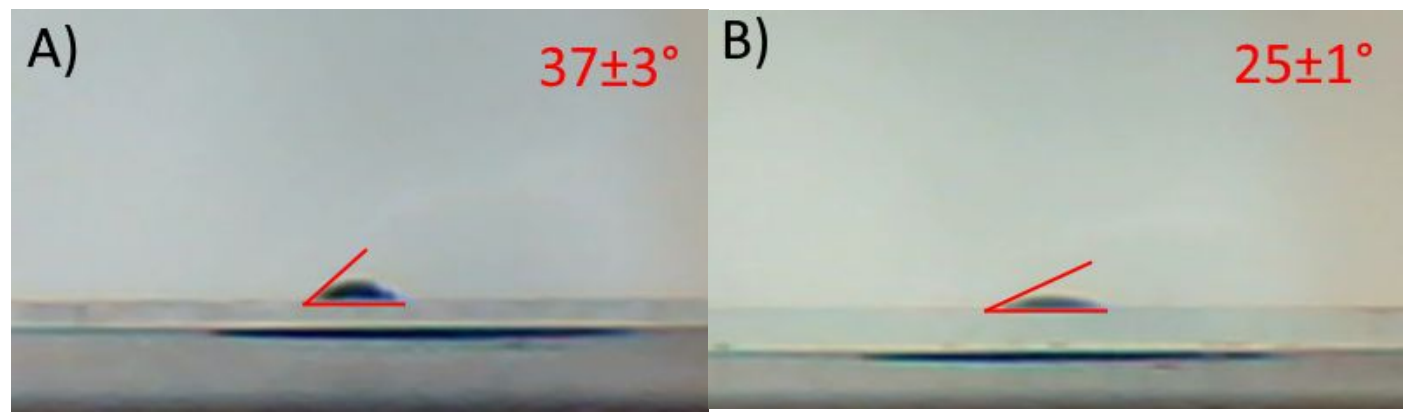

Figure S24. Contact angle of acetonitrile drop (1 $\mu \mathrm{L})$ on A) ITO/glass surface and B) FTO/glass surface. 


\section{Electrochemical impedance spectroscopy (EIS)}

EIS was measured for the Fe(t-tpy) system on each of the four substrates. The cyclic voltammograms (CVs) for each substrate with and without Fe(t-tpy) were given in Figure S25A, and then the impedance compared for the double layer (Dbl) region and the half-wave potential (Figure S25B) for the $\left[\mathrm{Fe}(\mathrm{t}-\mathrm{tpy})_{2}\right]$ functionalized films. The solution resistance was subtracted from the system. Here, the half-wave impedance was fit to an equivalent circuit similar to that by Vergaz $^{6}$ (Figure S25E). The series capacitance (Figure S25C) maximizes at the half-wave potential. These values were summarized in Table 1 where pseudocapacitance was calculated using Equation S3. Here, $C_{T}$ represents the limiting capacitance, $C_{F}$ is the Faradaic component, and $C_{d l}$ is the double-layer contribution., ${ }^{7,8}$

$$
C_{F}=C_{T}-C_{d l}
$$

Eq. S3
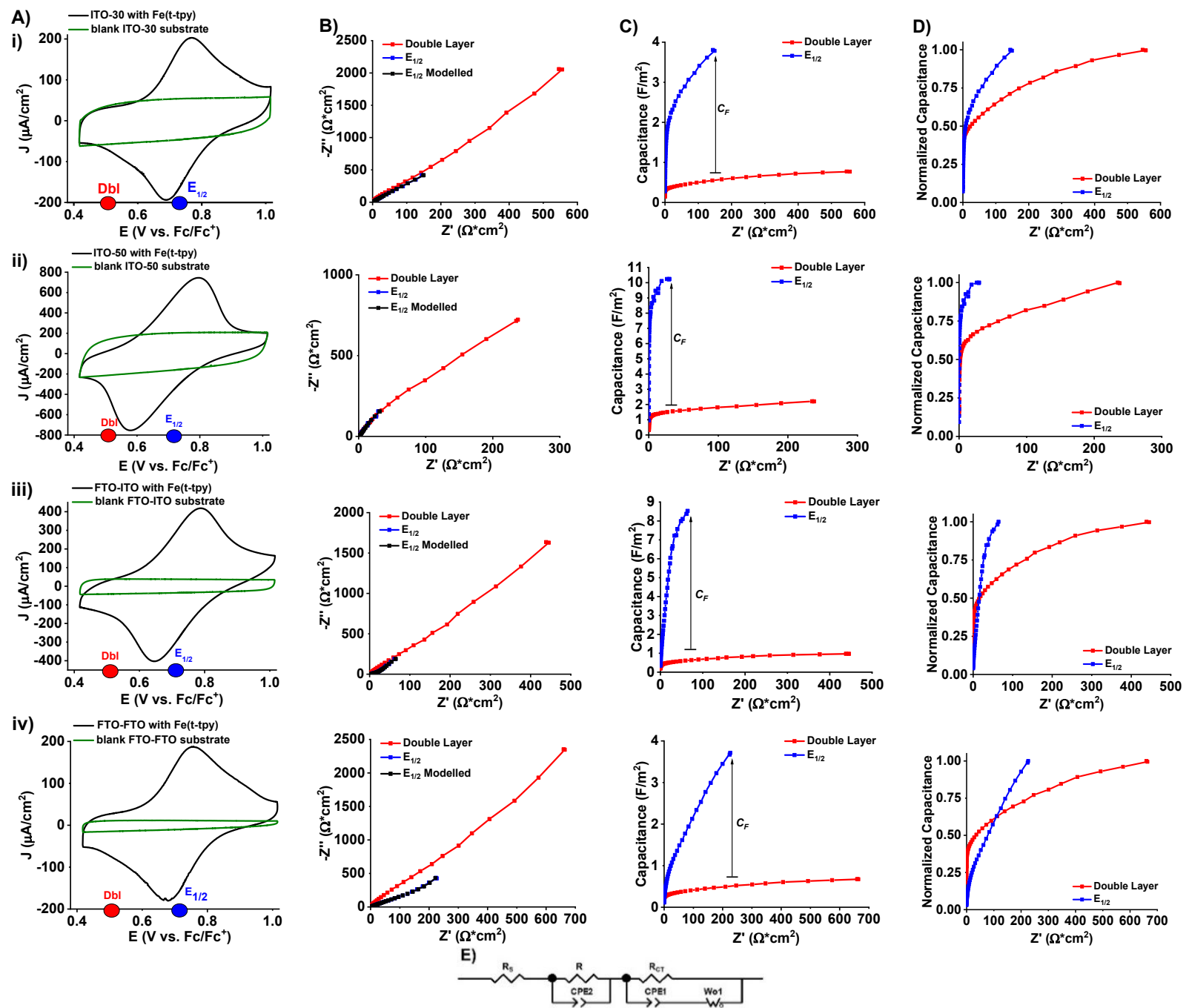

Figure S25: EIS data for $\left[\mathrm{Fe}(\mathrm{t}-\mathrm{tpy})_{2}\right]$ on different substrates: A) cyclic voltammogram at $50 \mathrm{mV} / \mathrm{s}$, B) Nyquist plot, C) capacitance plot, and C) normalized capacitance plot on i) ITO-30/ITO/glass, ii) ITO-50/ITO/glass, iii) FTO/ITO/glass, and iv) FTO/FTO/glass. E) the used equivalent circuit. 

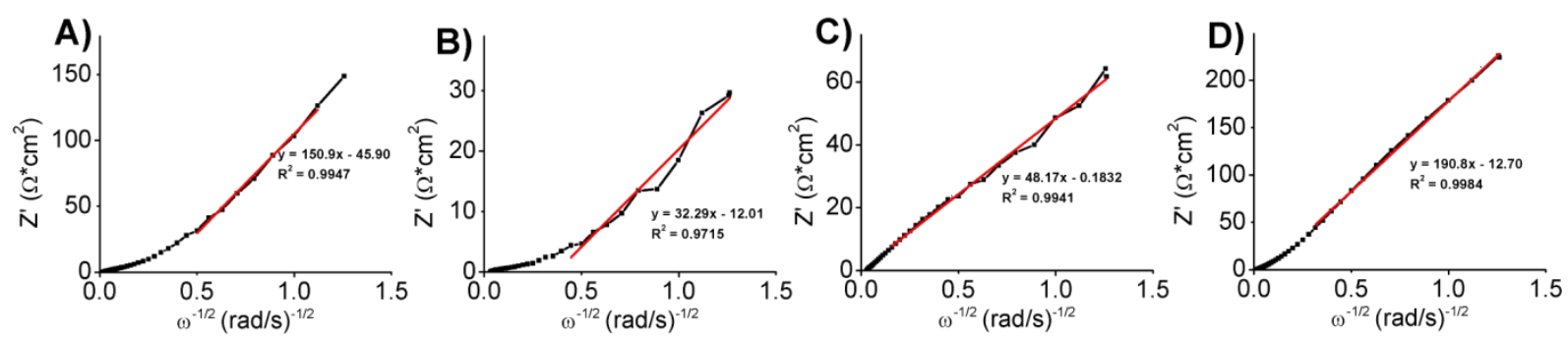

Figure S26: The relationship between impedance and reciprocal square root of frequency used for calculations of the Warburg coefficient $(\sigma)$ and the diffusion coefficient $(D)$. A) ITO-30, B) ITO-50, C) FTO-ITO, and D) FTO-FTO

$$
\begin{aligned}
& Z^{\prime}(\omega)=\frac{\sigma}{\sqrt{\omega}} \\
& \sigma=\frac{R T}{n^{2} F^{2} A \sqrt{2}}\left(\frac{1}{D^{1 / 2} C^{*}}\right)
\end{aligned}
$$

Eq. S4

Eq. S5
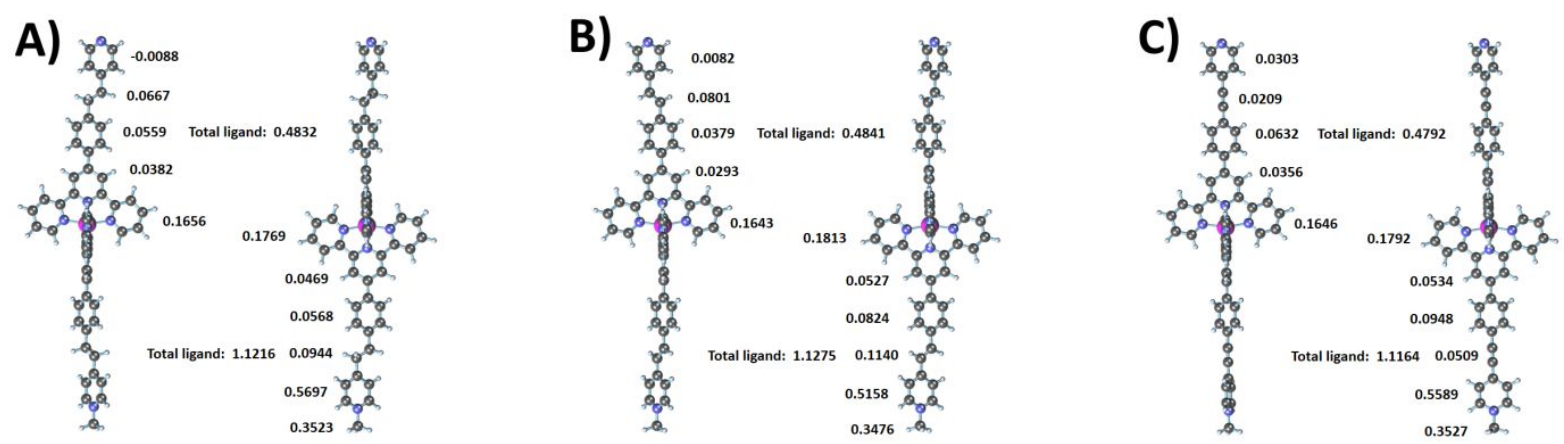

Figure S27: Charge distribution in A) $\left[\mathrm{Fe}(\mathrm{s}-\mathrm{tpy})_{2} \mathrm{CH}_{3}\right]^{3+}$, B) $\left[\mathrm{Fe}(\mathrm{d}-\mathrm{tpy})_{2} \mathrm{CH}_{3}\right]^{3+}$, and C) $\left[\mathrm{Fe}(\mathrm{t} \text {-tpy })_{2} \mathrm{CH}_{3}\right]^{3+}$.

\section{Synthesis of 2,2':2':6"'-Terpyridine-based Ligands}

(E)-4'-(4-(2-(pyridin-4-yl)vinyl)phenyl)-2,2':6',2'"-terpyridine aka (d-tpy): 'BuOK $(2.40 \mathrm{~g}$, $21.4 \mathrm{mmol}$ ) was measured out under a direct flow of nitrogen and added into round bottom flask. $3.50 \mathrm{~g}$ of 4-(2,2':6',2'-terpyridyl-4')-benzyl(triphenyl)phosphonium bromide (8.71 mmol) was added to $120 \mathrm{~mL}$ of anhydrous $\mathrm{DMF}$, and this was added to the reaction mixture. It was stirred at room temperature for 20 minutes, after which $0.50 \mathrm{~mL}$ 4-pyridine carboxaldehyde $(5.3 \mathrm{mmol})$ was added forming a dark-orange solution. This was heated at reflux for $4 \mathrm{~h}$, then stirred at room temperature for $3 \mathrm{~h}$. The mixture was extracted with $\mathrm{CHCl}_{3}(3 \times 100 \mathrm{~mL})$ yielding a yellow precipitate. The filtrate was washed with $150 \mathrm{~mL}$ chilled $\mathrm{H}_{2} \mathrm{O}$ and refrigerated overnight. The organic layer was evaporated under reduced pressure yielding a yellow oil. This was recrystallized in acetone obtaining a yellow solid (Yield: $410 \mathrm{mg}, 19 \%$ ). The ligand was obtained following the literature procedure, the NMR data fits the reported. ${ }^{9}$

FT-IR: v/cm ${ }^{-1} 3051 \mathrm{w}(\mathrm{C}-\mathrm{H}), 3012 \mathrm{w}(\mathrm{C}-\mathrm{H}), 1574 \mathrm{vs}(\mathrm{C}=\mathrm{C}-\mathrm{C}), 1468 \mathrm{~s}(\mathrm{C}=\mathrm{C}-$ C), 1384s (C-H), 1185s (C-H aromatic), 1115s (C-H aromatic), 972s (C-H trans), 779vs (C-H aromatic), 706vs (C-H aromatic). $\mathrm{UV}\left(\mathrm{CH}_{3} \mathrm{CN}\right): \lambda_{\max }$ $(\varepsilon) / \mathrm{nm}\left(\mathrm{L} \mathrm{mol}^{-1} \mathrm{~cm}^{-1}\right): 233\left(2.9 \times 10^{4}\right), 251 \mathrm{sh}\left(2.1 \times 10^{4}\right), 285\left(3.2 \times 10^{4}\right), 326$ $\left(4.9 \times 10^{4}\right)$.

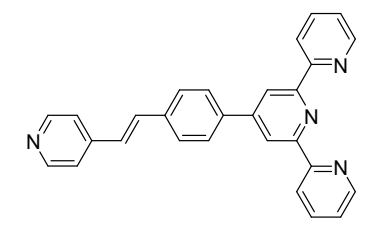


4'-(4-(2-(pyridin-4-yl)ethyl)phenyl)-2,2':6',2'-terpyridine (s-tpy): s-Tpy was obtained by the reduction of d-tpy using $\mathrm{NaBH}_{4}$ and acetic acid in the presence of $\mathrm{Pd} / \mathrm{C}$ catalyst. ${ }^{10}$ It was purified over an alumina column (99:1 $\left.\mathrm{CHCl}_{3}: \mathrm{MeOH}\right)$. Yield: $95.8 \mathrm{mg}, 47.7 \%$.

${ }^{1} \mathrm{H}$ NMR (400 MHz, DMSO-d $\left.{ }_{6}\right) \delta 8.74(\mathrm{ddd}, J=4.7,1.6,0.8 \mathrm{~Hz}, 1 \mathrm{H}), 8.68$ $(\mathrm{s}, 1 \mathrm{H}), 8.64(\mathrm{~d}, J=7.9 \mathrm{~Hz}, 1 \mathrm{H}), 8.44(\mathrm{dd}, J=4.4,1.6 \mathrm{~Hz}, 1 \mathrm{H}), 8.01$ (td, $J$ $=7.8,1.8 \mathrm{~Hz}, 1 \mathrm{H}), 7.82(\mathrm{~d}, J=8.2 \mathrm{~Hz}, 1 \mathrm{H}), 7.50(\mathrm{ddd}, J=7.4,4.8,1.1 \mathrm{~Hz}$, $1 \mathrm{H}), 7.43(\mathrm{~d}, J=8.2 \mathrm{~Hz}, 1 \mathrm{H}), 7.26(\mathrm{dd}, J=4.5,1.5 \mathrm{~Hz}, 1 \mathrm{H}), 3.04-2.94(\mathrm{~m}$, 2H). ${ }^{13} \mathrm{C}$ NMR (101 MHz, DMSO-d 6 ) $\delta 155.45,154.77,149.92,149.22$,

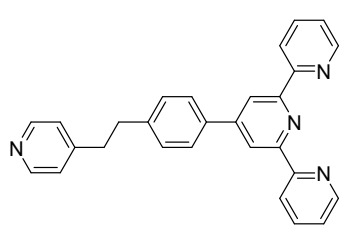
$149.13,149.07,142.38,137.25,134.94,129.26,126.59,124.20,123.80,120.72,117.50,35.52$, 30.47. FT-IR: $v / \mathrm{cm}^{-1} 3053 \mathrm{w}\left(\mathrm{C}-\mathrm{H}\right.$ aromatic), 2930s $\left(\mathrm{CH}_{2}\right), 2855 \mathrm{w}\left(\mathrm{CH}_{2}\right), 1585 \mathrm{~s}(\mathrm{C}=\mathrm{C}-\mathrm{C}), 1462 \mathrm{~s}$ $(\mathrm{C}=\mathrm{C}-\mathrm{C}), 1380 \mathrm{~s}(\mathrm{C}-\mathrm{N}), 1256 \mathrm{~s}(\mathrm{C}-\mathrm{N}), 1072 \mathrm{w}$ (C-H aromatic), 1031w (C-H aromatic), 983w $(\mathrm{C}=\mathrm{C})$, $793 \mathrm{vs}\left(\mathrm{C}-\mathrm{H}\right.$ aromatic), 750s $\left(\mathrm{C}-\mathrm{H}\right.$ aromatic), 660s $\left(\mathrm{CH}_{2}\right), 618 \mathrm{~s}\left(\mathrm{CH}_{2}\right) . \mathrm{UV}\left(\mathrm{CH}_{3} \mathrm{CN}\right): \lambda_{\max }(\varepsilon) / \mathrm{nm}$ $\left(\mathrm{L} \mathrm{mol}^{-1} \mathrm{~cm}^{-1}\right): 228\left(2.3 \times 10^{4}\right), 253\left(3.2 \times 10^{4}\right), 278\left(3.8 \times 10^{4}\right), 315 \mathrm{sh}\left(8.9 \times 10^{3}\right)$.

4'-(4-(pyridin-4-ylethynyl)phenyl)-2,2':6',2'-terpyridine (t-tpy): obtained according to the literature report, NMR data fits the reported. ${ }^{11} \mathrm{UV}\left(\mathrm{CH}_{3} \mathrm{CN}\right): \lambda_{\max }(\varepsilon) / \mathrm{nm}\left(\mathrm{L} \mathrm{mol}^{-1} \mathrm{~cm}^{-1}\right): 227$ $\left(2.3 \times 10^{4}\right), 255\left(1.8 \times 10^{4}\right), 301\left(4.0 \times 10^{4}\right)$.

\section{Synthesis of Quaternized Ligands}

Ligands were synthesized according to the published procedure. ${ }^{12}$ The quaternized single bond ligand was obtained as a yellow powder (Yield: $57.8 \mathrm{mg}, 57 \%$ ). The quaternized double bond ligand was obtained as a yellow-orange solid (Yield: $42.4 \mathrm{mg}, 75 \%$ ). The quaternized triple bond ligand was additionally separated over alumina using a mixture of dichloromethane and methanol (95:5). The desired ligand was collected as the second of three elutions, obtaining an orange-brown precipitate (Yield: $22.2 \mathrm{mg}, 26 \%$ ).

(4-(4-([2,2':6',2'"-terpyridin]-4'-yl)phenethyl)-1-methylpyridin-1-ium)I: ${ }^{1} \mathrm{H}$ NMR (400 MHz, DMSO) $\delta 8.86(\mathrm{~d}, J=6.5 \mathrm{~Hz}, 2 \mathrm{H}), 8.77(\mathrm{~d}, J=4.4 \mathrm{~Hz}$, $2 \mathrm{H}), 8.70(\mathrm{~s}, 2 \mathrm{H}), 8.68(\mathrm{~d}, J=8.0 \mathrm{~Hz}, 2 \mathrm{H}), 8.09-8.01(\mathrm{~m}, 4 \mathrm{H}), 7.88(\mathrm{~d}, J=$ $8.1 \mathrm{~Hz}, 2 \mathrm{H}), 7.54(\mathrm{dd}, J=7.0,5.1 \mathrm{~Hz}, 2 \mathrm{H}), 7.49(\mathrm{~d}, J=8.1 \mathrm{~Hz}, 2 \mathrm{H}), 4.28(\mathrm{~s}$,

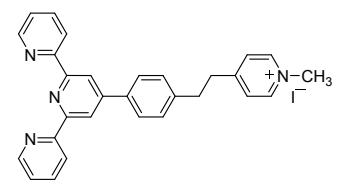
$3 \mathrm{H}), 3.29$ (d, $J=8.0 \mathrm{~Hz}, 2 \mathrm{H}), 3.13(\mathrm{t}, J=7.7 \mathrm{~Hz}, 2 \mathrm{H}) .{ }^{13} \mathrm{C}$ NMR (101 MHz, DMSO) $\delta 160.89$, $155.70,154.95,149.36,149.23,144.83,141.56,137.54,135.47,129.54,127.46,126.97,124.60$, 120.97, 117.74, 47.22, 35.78, 34.32. FT-IR: v/cm-1 3412b ( $>\mathrm{N}-\mathrm{H}), 2922 \mathrm{w}\left(\mathrm{CH}_{2}\right), 2849 \mathrm{w}\left(\mathrm{CH}_{2}\right)$, 1637 vs $(\mathrm{C}=\mathrm{C}-\mathrm{C}), 1582$ vs $(\mathrm{C}=\mathrm{C}-\mathrm{C}), 1562$ vs $(\mathrm{C}=\mathrm{C}-\mathrm{C}), 1520 \mathrm{vs}(\mathrm{C}=\mathrm{C}-\mathrm{C}), 1462 \mathrm{vs}(\mathrm{C}=\mathrm{C}-\mathrm{C}), 1382 \mathrm{vs}$ (C-N), 1264 (C-N), 1180s (C-H aromatic), 1080s (C-H aromatic), 1031s (C-H aromatic), 983s $(\mathrm{C}=\mathrm{C}), 893 \mathrm{~s}$ (C-H aromatic), 835vs (C-H aromatic), 789vs (C-H aromatic), 734vs (C-H aromatic), 655vs $\left(\mathrm{C}-\mathrm{H}\right.$ aromatic). $\mathrm{UV}\left(\mathrm{CH}_{3} \mathrm{CN}\right): \lambda_{\max }(\varepsilon) / \mathrm{nm}\left(\mathrm{L} \mathrm{mol}^{-1} \mathrm{~cm}^{-1}\right): 252\left(4.8 \times 10^{4}\right), 278\left(4.2 \times 10^{4}\right)$, $320 \operatorname{sh}\left(7.3 \times 10^{3}\right)$.

((E)-4-(4-([2,2':6',2' '-terpyridin]-4'-yl)styryl)-1-methylpyridin-1-ium)I: ${ }^{1} \mathrm{H}$ NMR (400 MHz, DMSO) $\delta 8.91(\mathrm{~d}, J=6.7 \mathrm{~Hz}, 2 \mathrm{H}), 8.80-8.78(\mathrm{~m}, 4 \mathrm{H})$, $8.71(\mathrm{~d}, J=7.9 \mathrm{~Hz}, 2 \mathrm{H}), 8.29(\mathrm{~d}, J=6.8 \mathrm{~Hz}, 2 \mathrm{H}), 8.16-8.10(\mathrm{~m}, 2 \mathrm{H}), 8.07$ $(\mathrm{dt}, J=7.8,1.8 \mathrm{~Hz}, 2 \mathrm{H}), 8.00-7.94(\mathrm{~m}, 2 \mathrm{H}), 7.67(\mathrm{~d}, J=16.3 \mathrm{~Hz}, 2 \mathrm{H}), 7.59$

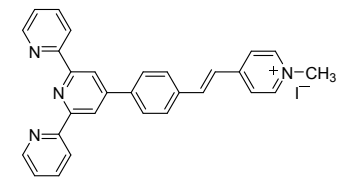
7.52 (m, 2H), 4.28 (s, 3H). ${ }^{13} \mathrm{C}$ NMR (101 MHz, DMSO) $\delta 154.76,149.17,145.06,143.07,137.30$, 
131.31, 131.22, 129.90, 128.87, 128.61, 128.52, 127.52, 124.47, 124.12, 123.53, 118.84, 117.63, 47.56. FT-IR: $v / \mathrm{cm}^{-1} 3406 \mathrm{~b}(>\mathrm{N}-\mathrm{H}), 3010 \mathrm{vs}(\mathrm{C}-\mathrm{H}), 2942 \mathrm{w}\left(\mathrm{CH}_{3}\right), 1651 \mathrm{vs}(\mathrm{C}=\mathrm{C}), 1611 \mathrm{vs}(\mathrm{C}=\mathrm{C}-$ C), 1574vs $(\mathrm{C}=\mathrm{C}-\mathrm{C}), 1515$ vs $(\mathrm{C}=\mathrm{C}-\mathrm{C}), 1472$ vs $(\mathrm{C}=\mathrm{C}-\mathrm{C}), 1386 \mathrm{vs}(\mathrm{C}-\mathrm{N}), 1338 \mathrm{~s}(\mathrm{C}-\mathrm{H}), 1256 \mathrm{~s}(\mathrm{C}-$ $\mathrm{N}), 1178 \mathrm{vs}(\mathrm{C}-\mathrm{H}$ aromatic), 1119vs (C-H aromatic), 972vs (C-H trans), 836vs (C-H aromatic), $779 \mathrm{vs}(\mathrm{C}-\mathrm{H}$ aromatic), 738s (C-H aromatic), 711s (C-H aromatic), 685s (C-H aromatic). UV $\left(\mathrm{CH}_{3} \mathrm{CN}\right): \lambda_{\max }(\varepsilon) / \mathrm{nm}\left(\mathrm{L} \mathrm{mol}^{-1} \mathrm{~cm}^{-1}\right): 247\left(4.5 \times 10^{4}\right), 278\left(2.8 \times 10^{4}\right), 361\left(3.6 \times 10^{4}\right)$.

(4-((4-([2,2':6',2"-terpyridin]-4'-yl)phenyl)ethynyl)-1-methylpyridin-1ium)I: ${ }^{1} \mathrm{H}$ NMR $\left(400 \mathrm{MHz}, \mathrm{CD}_{3} \mathrm{CN}\right) \delta 8.77(\mathrm{~s}, 2 \mathrm{H}), 8.73-8.65(\mathrm{~m}, 4 \mathrm{H})$, $8.57(\mathrm{~d}, J=6.6 \mathrm{~Hz}, 2 \mathrm{H}), 8.05-8.00(\mathrm{~m}, 4 \mathrm{H}), 7.97(\mathrm{t}, J=7.7 \mathrm{~Hz}, 2 \mathrm{H}), 7.86$ $(\mathrm{d}, J=8.1 \mathrm{~Hz}, 2 \mathrm{H}), 7.45(\mathrm{t}, J=5.8 \mathrm{~Hz}, 2 \mathrm{H}), 4.24(\mathrm{~s}, 3 \mathrm{H}) .{ }^{13} \mathrm{C}$ NMR $(101$

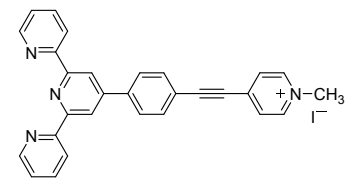
$\left.\mathrm{MHz}, \mathrm{CD}_{3} \mathrm{CN}\right) \delta 148.80,146.11,144.45,138.30,138.25,135.70,135.60,134.35,130.34,128.73$, 126.52, 125.33, 122.81, 122.65, 120.14, 119.37, 108.14, 105.56, 53.66. FT-IR: $v / \mathrm{cm}^{-1} 2969 \mathrm{vs}$ $\left(\mathrm{CH}_{3}\right), 2219 \mathrm{~s}(\mathrm{C} \equiv \mathrm{C}), 1621 \mathrm{w}(\mathrm{C}=\mathrm{C}-\mathrm{C}), 1580 \mathrm{w}(\mathrm{C}=\mathrm{C}-\mathrm{C}), 1562 \mathrm{w}(\mathrm{C}=\mathrm{C}-\mathrm{C}), 1523 \mathrm{w}(\mathrm{C}=\mathrm{C}-\mathrm{C}), 1460 \mathrm{w}$ $(\mathrm{C}=\mathrm{C}-\mathrm{C}), 1389 \mathrm{w}(\mathrm{C}-\mathrm{N}), 1258 \mathrm{vs}(\mathrm{C}-\mathrm{N}), 1084 \mathrm{vs}(\mathrm{C}-\mathrm{H}$ aromatic), 1009vs (C-H aromatic), 785vs (C$\mathrm{H}$ aromatic), $697 \mathrm{w}\left(\mathrm{C}-\mathrm{H}\right.$ aromatic), $658 \mathrm{w}\left(\mathrm{C}-\mathrm{H}\right.$ aromatic). $\mathrm{UV}\left(\mathrm{CH}_{3} \mathrm{CN}\right): \lambda_{\max }(\varepsilon) / \mathrm{nm}\left(\mathrm{L} \mathrm{mol}^{-1}\right.$ $\left.\mathrm{cm}^{-1}\right): 249\left(2.2 \times 10^{4}\right), 280\left(2.2 \times 10^{4}\right), 348\left(1.8 \times 10^{4}\right)$.

\section{Synthesis of Iron(II)-Terpyridine Metal Complexes}

The corresponding terpyridine ligand was dissolved in acetonitrile, and a half molar amount of $\mathrm{Fe}(\mathrm{BF} 4)_{2} * 6 \mathrm{H}_{2} \mathrm{O}$ salts was added. A purple colour was immediately observed upon iron addition. The complex was briefly sonicated, and then the solvent was removed under reduced pressure. $\mathrm{Fe}(\mathrm{d}-\mathrm{Tpy})_{2}$ was obtained according to literature reports. ${ }^{9}$

[Fe(4'-(4-(2-(pyridin-4-yl)ethyl)phenyl)-2,2':6',2"'terpyridine $\left.)_{2}\right]\left(\mathrm{BF}_{4}\right)_{2}$ aka $\left[\mathrm{Fe}(\mathrm{s} \text {-tpy })_{2}\right]\left(\mathrm{BF}_{4}\right)_{2}:{ }^{1} \mathrm{H} \mathrm{NMR}$ $\left(400 \mathrm{MHz}, \mathrm{DMSO}-\mathrm{d}_{6}\right) \delta 9.61(\mathrm{~s}, 4 \mathrm{H}), 9.02(\mathrm{~d}, J=8.1 \mathrm{~Hz}$, $4 \mathrm{H}), 8.61(\mathrm{~d}, J=4.5 \mathrm{~Hz}, 4 \mathrm{H}), 8.45(\mathrm{~d}, J=7.7 \mathrm{~Hz}, 4 \mathrm{H})$, $7.99(\mathrm{t}, J=7.7 \mathrm{~Hz}, 4 \mathrm{H}), 7.63(\mathrm{~d}, J=8.0 \mathrm{~Hz}, 4 \mathrm{H}), 7.57(\mathrm{~s}$,

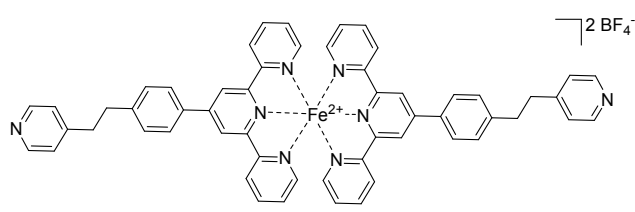
$4 \mathrm{H}), 7.23(\mathrm{~d}, J=5.2 \mathrm{~Hz}, 4 \mathrm{H}), 7.15(\mathrm{t}, J=6.2 \mathrm{~Hz}, 4 \mathrm{H}), 3.17(\mathrm{~s}, 4 \mathrm{H}) .{ }^{13} \mathrm{C}$ NMR $(101 \mathrm{MHz}, \mathrm{DMSO})$ $\delta 160.30,158.35,156.85,153.22,141.63,139.18,134.06,130.05,128.15,128.00,125.60,124.51$, 121.19, 100.82, 99.13, 36.30, 35.47. $[\mathrm{M}+]^{2+}$ Calc for $\mathrm{C}_{56} \mathrm{H}_{44} \mathrm{FeN}_{8}$ 442.15137; Found 442.15127. $[\mathrm{M}+2 \mathrm{H}]^{2+}$ Calc for $\mathrm{C}_{56} \mathrm{H}_{44} \mathrm{FeN}_{8}$ 443.157276; Found 443.15360. FT-IR: $v / \mathrm{cm}^{-1} 3396 \mathrm{~b}(>\mathrm{N}-\mathrm{H})$, $3075 \mathrm{w}\left(\mathrm{C}-\mathrm{H}\right.$ aromatic), 2922w $\left(\mathrm{CH}_{2}\right), 2853 \mathrm{w}\left(\mathrm{CH}_{2}\right), 1613 \mathrm{~s}(\mathrm{C}=\mathrm{C}-\mathrm{C}), 1411 \mathrm{~s}(\mathrm{C}=\mathrm{C}-\mathrm{C}), 1048 \mathrm{vs}(\mathrm{C}-$ $\mathrm{H}$ aromatic), 832s (C-H aromatic), 785s (C-H aromatic), 732vs (C-H aromatic), 654vs (C-H aromatic). $\mathrm{UV}\left(\mathrm{CH}_{3} \mathrm{CN}\right): \lambda_{\max }(\varepsilon) / \mathrm{nm}\left(\mathrm{L} \mathrm{mol}^{-1} \mathrm{~cm}^{-1}\right): 286\left(7.2 \times 10^{4}\right), 308 \mathrm{sh}\left(6.3 \times 10^{4}\right), 321$ $\left(6.6 \times 10^{4}\right), 568\left(2.6 \times 10^{4}\right)$.

[Fe((E)-4'-(4-(2-(pyridin-4-yl)vinyl)phenyl)-2,2':6',2'"terpyridine $\left.)_{2}\right]\left(\mathrm{BF}_{4}\right)_{2}$ aka $\left[\mathbf{F e}(\mathrm{d}-\mathrm{tpy})_{2}\right]\left(\mathrm{BF}_{4}\right)_{2}:{ }^{1} \mathrm{H}$ NMR $(400 \mathrm{MHz}, \mathrm{DMSO}-\mathrm{d} 6) \delta 9.74(\mathrm{~s}, 1 \mathrm{H}), 9.10(\mathrm{~d}, J=8.1 \mathrm{~Hz}$, $1 \mathrm{H}), 8.69-8.63(\mathrm{~m}, 2 \mathrm{H}), 8.12(\mathrm{~d}, J=8.5 \mathrm{~Hz}, 1 \mathrm{H}), 8.05$ (td, $J=7.8,1.4 \mathrm{~Hz}, 1 \mathrm{H}), 7.78(\mathrm{~d}, J=16.4 \mathrm{~Hz}, 1 \mathrm{H}), 7.68(\mathrm{dd}, J$

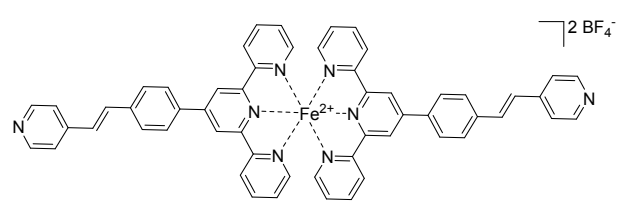
$=4.7,1.5 \mathrm{~Hz}, 1 \mathrm{H}), 7.59(\mathrm{~d}, J=16.4 \mathrm{~Hz}, 1 \mathrm{H}), 7.30(\mathrm{~d}, J=5.5 \mathrm{~Hz}, 1 \mathrm{H}), 7.22-7.18(\mathrm{~m}, 1 \mathrm{H}) .{ }^{13} \mathrm{C}$ NMR (101 MHz, DMSO-d6) $\delta$ 160.13, 158.10, 155.80, 153.01, 150.41, 148.32, 144.26, 138.99, $138.76,135.79,132.32,128.38,128.29,127.80,124.32,121.23,120.94$. FT-IR: $v / \mathrm{cm}^{-1} 3548 \mathrm{~b}(>\mathrm{N}-$ 
H), 3080b (C-H aromatic), 1695s (C=C-C), 1619s $(\mathrm{C}=\mathrm{C}), 1421 \mathrm{~s}(\mathrm{C}=\mathrm{C}-\mathrm{C}), 1040 \mathrm{vs}(\mathrm{C}-\mathrm{H}$ aromatic $)$, 796vs (C-H aromatic), $614 \mathrm{~s}\left(\mathrm{C}-\mathrm{H}\right.$ aromatic). $\mathrm{UV}\left(\mathrm{CH}_{3} \mathrm{CN}\right): \lambda_{\max }(\varepsilon) / \mathrm{nm}\left(\mathrm{L} \mathrm{mol}^{-1} \mathrm{~cm}^{-1}\right): 243 \mathrm{sh}$ $\left(3.7 \times 10^{4}\right), 287\left(5.0 \times 10^{4}\right), 323 \mathrm{sh}\left(6.9 \times 10^{4}\right), 340\left(7.5 \times 10^{4}\right), 362 \mathrm{sh}\left(6.4 \times 10^{4}\right), 574\left(3.1 \times 10^{4}\right)$.

[Fe(4'-(4-(pyridin-4-ylethynyl)phenyl)-2,2':6',2'"terpyridine $\left.)_{2}\right]\left(\mathbf{B F}_{4}\right)_{2}$ aka $\left[\mathbf{F e}(\mathbf{t}-t p y)_{2}\right]\left(\mathbf{B F}_{4}\right)_{2}:{ }^{1} \mathrm{H} \mathrm{NMR}(400$ MHz, DMSO) $\delta 9.76(\mathrm{~s}, 4 \mathrm{H}), 9.10(\mathrm{~d}, J=7.6 \mathrm{~Hz}, 4 \mathrm{H}), 8.83$ $-8.65(\mathrm{~m}, 8 \mathrm{H}), 8.17-8.00(\mathrm{~m}, 8 \mathrm{H}), 7.69(\mathrm{~s}, 4 \mathrm{H}), 7.30(\mathrm{~d}, J$

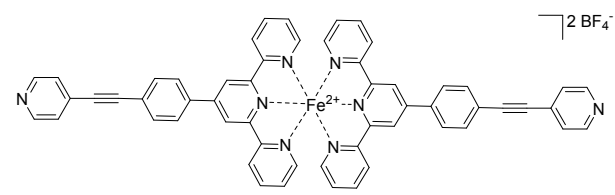
$=4.5 \mathrm{~Hz}, 4 \mathrm{H}), 7.21(\mathrm{~d}, J=6.5 \mathrm{~Hz}, 4 \mathrm{H}) .{ }^{13} \mathrm{C}$ NMR (101 MHz, DMSO) $\delta 160.51,158.29,153.34$, $150.51,150.07,139.33,137.26,133.31,128.62$, 128.09, 126.12, 124.68, 123.78, 121.46, 110.78, 73.06, 68.54 FT-IR: $v / \mathrm{cm}^{-1} 3538 \mathrm{~b}(>\mathrm{N}-\mathrm{H}), 3077 \mathrm{w}(\mathrm{C}-\mathrm{H}$ aromatic), 2207s $(\mathrm{C} \equiv \mathrm{C}), 1607 \mathrm{~s}(\mathrm{C}=\mathrm{C}-\mathrm{C})$, $1403 \mathrm{~s}(\mathrm{C}=\mathrm{C}-\mathrm{C}), 1033 \mathrm{vs}(\mathrm{C}-\mathrm{H}$ aromatic), 777vs $(\mathrm{C}-\mathrm{H}$ aromatic), 618s (C-H aromatic). UV $\left(\mathrm{CH}_{3} \mathrm{CN}\right): \lambda_{\max }(\varepsilon) / \mathrm{L} \mathrm{mol}^{-1} \mathrm{~cm}^{-1} 242 \mathrm{sh}\left(3.5 \times 10^{4}\right), 288\left(4.8 \times 10^{4}\right), 325\left(7.1 \times 10^{4}\right), 574\left(2.5 \times 10^{4}\right)$.

[Fe(4-(4-([2,2':6',2'-terpyridin]-4'-yl)phenethyl)1-methylpyridin-1-ium $)]_{2}\left(\mathrm{BF}_{4}\right)_{2}$ aka $\left[\mathrm{Fe}\left(\mathrm{CH}_{3}\right.\right.$-stpy) $\mathbf{2}_{\mathbf{2}} \mathbf{I}_{\mathbf{2}}\left(\mathbf{B F}_{\mathbf{4}}\right)_{\mathbf{2}}:{ }^{1} \mathrm{H}$ NMR (400 MHz, DMSO) $\delta 9.67$ $(\mathrm{s}, 4 \mathrm{H}), 9.07(\mathrm{~d}, J=8.2 \mathrm{~Hz}, 4 \mathrm{H}), 8.94(\mathrm{~d}, J=6.6 \mathrm{~Hz}$, $4 \mathrm{H}), 8.52(\mathrm{t}, J=9.5 \mathrm{~Hz}, 4 \mathrm{H}), 8.15(\mathrm{~d}, J=6.4 \mathrm{~Hz}$,

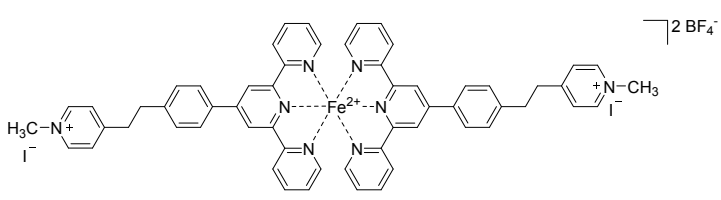
$4 \mathrm{H}), 8.05(\mathrm{t}, J=7.7 \mathrm{~Hz}, 4 \mathrm{H}), 7.74(\mathrm{~d}, J=8.1 \mathrm{~Hz}, 4 \mathrm{H}), 7.27(\mathrm{q}, J=6.3 \mathrm{~Hz}, 4 \mathrm{H}), 7.20(\mathrm{t}, J=6.4 \mathrm{~Hz}$, 4H), 4.33 (s, 6H), $3.27-3.21(\mathrm{~m}, 8 \mathrm{H}) .{ }^{13} \mathrm{C}$ NMR (101 MHz, DMSO) $\delta 165.65,159.26,155.21$, 154.34, 147.79, 145.43, 139.65, 139.34, 130.43, 129.95, 128.34, 127.93, 127.40, 124.53, 119.78, 44.75, 39.36. FT-IR: $v / \mathrm{cm}^{-1} 2963 \mathrm{~s}\left(\mathrm{CH}_{3}\right), 1625 \mathrm{w}(\mathrm{C}=\mathrm{C}-\mathrm{C}), 1556 \mathrm{w}(\mathrm{C}=\mathrm{C}-\mathrm{C}), 1521 \mathrm{w}(\mathrm{C}=\mathrm{C}-\mathrm{C})$, 1476w $(\mathrm{C}=\mathrm{C}-\mathrm{C}), 1382 \mathrm{w}\left(\mathrm{CH}_{3}\right), 1258 \mathrm{vs}(\mathrm{C}-\mathrm{N})$, 1080vs $(\mathrm{C}-\mathrm{H}$ aromatic $), 1017 \mathrm{vs}(\mathrm{C}-\mathrm{H}$ aromatic), $793 \mathrm{vs}\left(\mathrm{C}-\mathrm{H}\right.$ aromatic). UV $\left(\mathrm{CH}_{3} \mathrm{CN}\right): \lambda_{\max }(\varepsilon) / \mathrm{nm}\left(\mathrm{L} \mathrm{mol}^{-1} \mathrm{~cm}^{-1}\right): 247\left(8.0 \times 10^{4}\right), 285\left(8.8 \times 10^{4}\right)$, $320\left(6.5 \times 10^{4}\right), 368 \operatorname{sh}\left(9.6 \times 10^{3}\right), 569\left(2.7 \times 10^{4}\right)$.

[Fe((E)-4-(4-([2,2':6',2'-terpyridin]-4'-yl)styryl)1-methylpyridin-1-ium $)]_{2}\left(\mathrm{BF}_{4}\right)_{2}$ aka $\left[\mathrm{Fe}\left(\mathrm{CH}_{3}\right.\right.$-dtpy) $\mathbf{2}_{\mathbf{2}} \mathbf{I}_{\mathbf{2}}\left(\mathbf{B F}_{\mathbf{4}}\right)_{\mathbf{2}}:{ }^{1} \mathrm{H}$ NMR (400 MHz, DMSO) $\delta 9.77$ $(\mathrm{s}, 4 \mathrm{H}), 9.11(\mathrm{~d}, J=8.0 \mathrm{~Hz}, 4 \mathrm{H}), 8.96(\mathrm{~d}, J=6.5 \mathrm{~Hz}$,

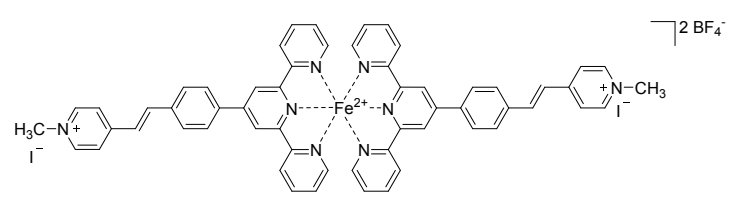
$4 \mathrm{H}), 8.74(\mathrm{~d}, J=7.9 \mathrm{~Hz}, 4 \mathrm{H}), 8.33(\mathrm{~d}, J=6.5 \mathrm{~Hz}$, 4H), $8.20(\mathrm{~d}, J=6.4 \mathrm{~Hz}, 4 \mathrm{H}), 8.06(\mathrm{~d}, J=7.6 \mathrm{~Hz}, 4 \mathrm{H}), 7.67-7.59(\mathrm{~m}, 4 \mathrm{H}), 7.59-7.53(\mathrm{~m}, 4 \mathrm{H})$, $7.30(\mathrm{dd}, J=12.2,7.2 \mathrm{~Hz}, 2 \mathrm{H}), 7.22(\mathrm{dd}, J=13.3,6.2 \mathrm{~Hz}, 2 \mathrm{H}), 4.33(\mathrm{~s}, 6 \mathrm{H}) .{ }^{13} \mathrm{C}$ NMR $(101 \mathrm{MHz}$, DMSO) $\delta 159.15,157.65,156.10,152.33,145.18,145.05,138.64,135.96,135.24,131.83,131.22$, 129.22, 128.23, 127.08, $125.70,123.58,119.21,50.12$. FT-IR: $v / \mathrm{cm}^{-1} 3410 \mathrm{~b}(>\mathrm{N}-\mathrm{H}), 3008 \mathrm{vs}(\mathrm{C}-$ $\mathrm{H}), 2942 \mathrm{w}\left(\mathrm{CH}_{3}\right), 1647 \mathrm{vs}(\mathrm{C}=\mathrm{C}), 1616 \mathrm{vs}(\mathrm{C}=\mathrm{C}-\mathrm{C}), 1515 \mathrm{vs}(\mathrm{C}=\mathrm{C}-\mathrm{C}), 1462 \mathrm{vs}(\mathrm{C}=\mathrm{C}-\mathrm{C}), 1405 \mathrm{~s}(\mathrm{C}-$ $\mathrm{H}), 1180 \mathrm{~s}$ (C-H aromatic), 1076vs (C-H aromatic), 834vs (C-H aromatic), 785vs (C-H aromatic), $751 \mathrm{~s}\left(\mathrm{C}-\mathrm{H}\right.$ aromatic). UV $\left(\mathrm{CH}_{3} \mathrm{CN}\right): \lambda_{\max }(\varepsilon) / \mathrm{nm}\left(\mathrm{L} \mathrm{mol}^{-1} \mathrm{~cm}^{-1}\right): 249\left(1.0 \times 10^{5}\right), 284\left(7.0 \times 10^{4}\right)$, $360\left(9.7 \times 10^{4}\right), 577\left(2.7 \times 10^{4}\right)$.

[Fe((4-((4-([2,2':6',2''-terpyridin]-4'yl)phenyl)ethynyl)-1-methylpyridin-1ium $) \mathrm{I})]_{2}\left(\mathrm{BF}_{4}\right)_{2}$ aka $\left[\mathrm{Fe}\left(\mathrm{CH}_{3} \text {-t-tpy }\right)\right]_{2} \mathbf{I}_{2}\left(\mathrm{BF}_{4}\right)_{2}:{ }^{1} \mathrm{H}$ NMR $\left(400 \mathrm{MHz}, \mathrm{CD}_{3} \mathrm{CN}\right) \delta 9.20(\mathrm{~s}, 4 \mathrm{H}), 8.62(\mathrm{~d}, J$

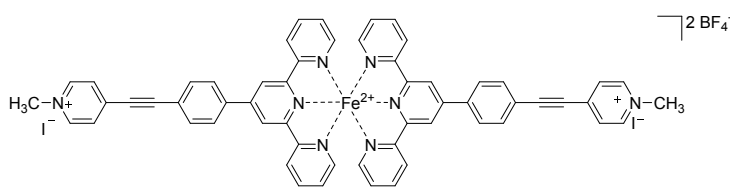
$=5.8 \mathrm{~Hz}, 8 \mathrm{H}), 8.48-8.34(\mathrm{~m}, 4 \mathrm{H}), 8.09(\mathrm{~d}, J=5.3 \mathrm{~Hz}, 8 \mathrm{H}), 7.91(\mathrm{~s}, 4 \mathrm{H}), 7.18(\mathrm{~s}, 4 \mathrm{H}), 7.08(\mathrm{~s}$, 
4H), 4.29 (s, 4H), 2.06 (s, 2H). ${ }^{13} \mathrm{C}$ NMR (101 MHz, $\left.\mathrm{CD}_{3} \mathrm{CN}\right) \delta 161.32,158.89,154.22,149.85$, $146.41,139.97,139.80,134.75,130.49,129.53,128.87,128.43,124.99,122.70,113.16,87.53$, 49.15, 30.77. FT-IR: v/cm-1 $3404(>\mathrm{N}-\mathrm{H}), 3029 \mathrm{w}\left(\mathrm{C}-\mathrm{H}\right.$ aromatic), 2961s $\left(\mathrm{CH}_{3}\right), 2217 \mathrm{~s}(\mathrm{C} \equiv \mathrm{C})$, 2184w $(\mathrm{C} \equiv \mathrm{C}), 1640 \mathrm{~s}(\mathrm{C}=\mathrm{C}-\mathrm{C}), 1605 \mathrm{~s}(\mathrm{C}=\mathrm{C}-\mathrm{C}), 1519 \mathrm{~s}(\mathrm{C}=\mathrm{C}-\mathrm{C}), 1466 \mathrm{~s}(\mathrm{C}=\mathrm{C}-\mathrm{C}), 1403 \mathrm{~s}(\mathrm{C}=\mathrm{C}-\mathrm{C})$, 1250vs (C-N), 1072vs (C-H aromatic), 1013vs (C-H aromatic), 781vs (C-H aromatic). UV $\left(\mathrm{CH}_{3} \mathrm{CN}\right): \lambda_{\max }(\varepsilon) / \mathrm{nm}\left(\mathrm{L} \mathrm{mol}^{-1} \mathrm{~cm}^{-1}\right): 242\left(5.3 \times 10^{4}\right), 285\left(5.7 \times 10^{4}\right), 335\left(7.3 \times 10^{4}\right), 576\left(2.6 \times 10^{4}\right)$.
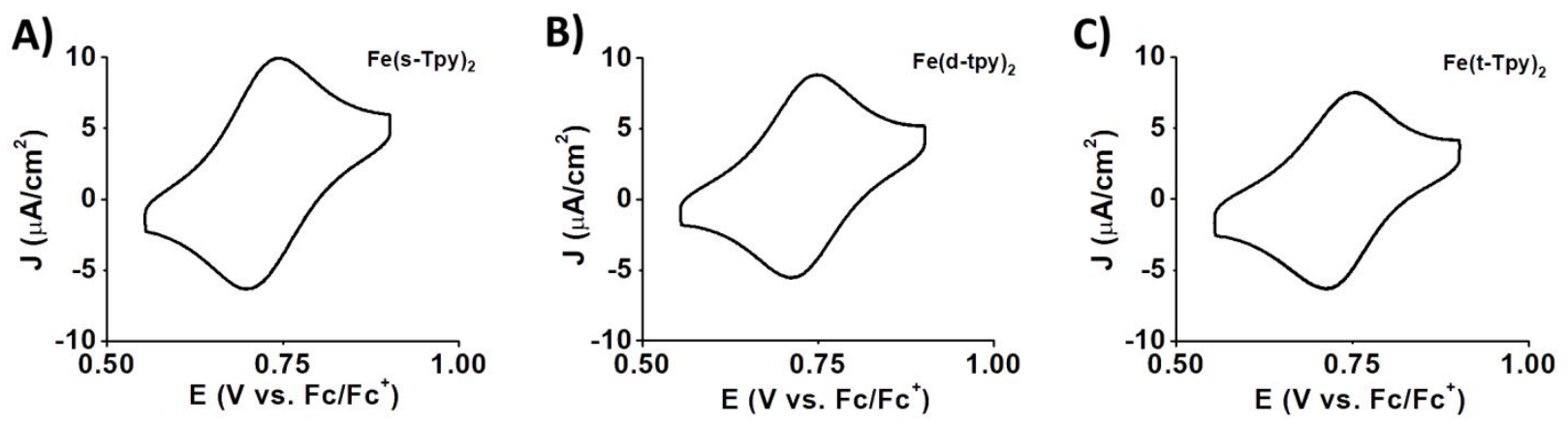

Figure S28: CVs of $0.1 \mathrm{mM}$ complexes in solution at $\left.50 \mathrm{mV} / \mathrm{s}(0.1 \mathrm{M} \text { TBAHFP/MeCN): A) Fe(s-tpy })_{2}\left(\mathrm{BF}_{4}\right)_{2}, \mathrm{~B}\right)$ $\mathrm{Fe}(\mathrm{d} \text {-tpy })_{2}\left(\mathrm{BF}_{4}\right)_{2}$, and $\left.\mathrm{C}\right) \mathrm{Fe}(\mathrm{t} \text {-tpy })_{2}\left(\mathrm{BF}_{4}\right)_{2}$.
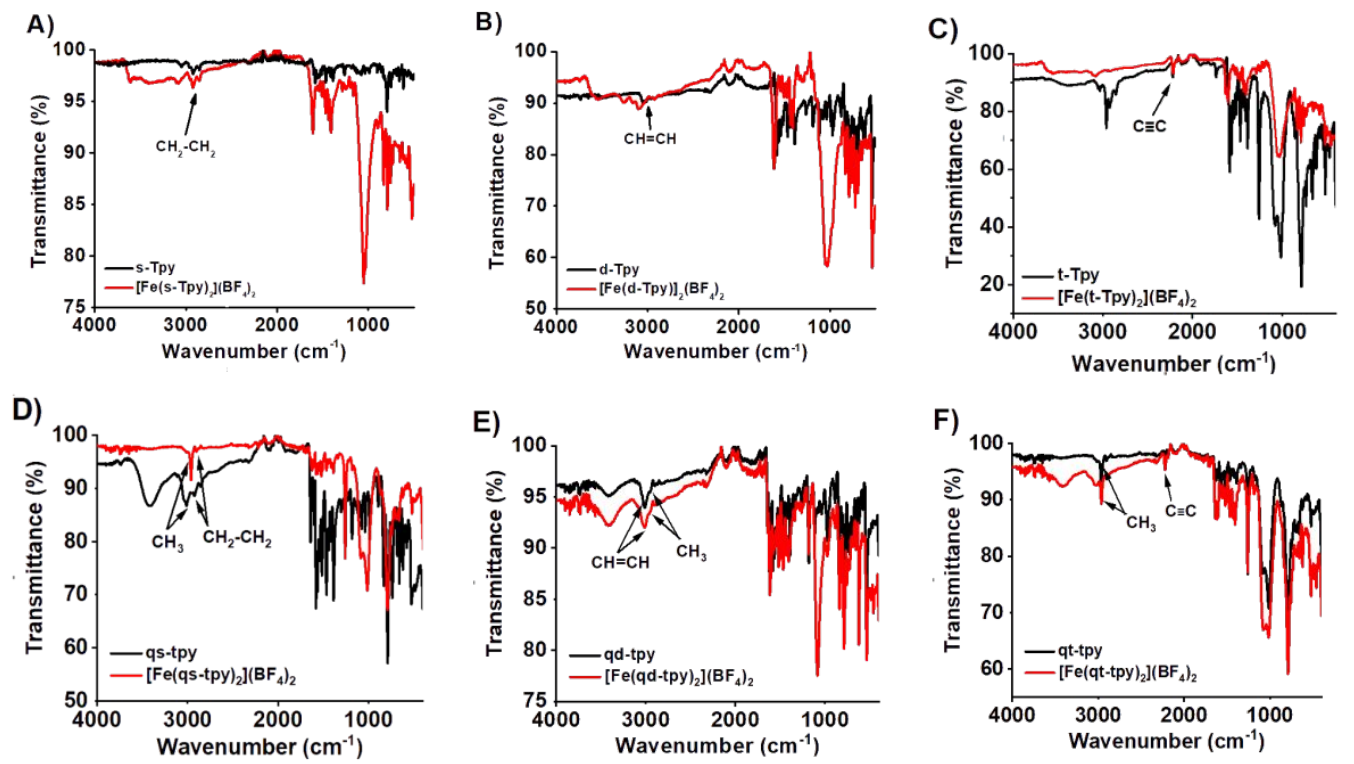

Figure S29: IR spectrum of tpy ligands and Fe-tpy complexes: a) s-tpy, b) d-tpy, c) t-tpy, d) qs-tpy, e) qd-tpy, f) qttpy). 


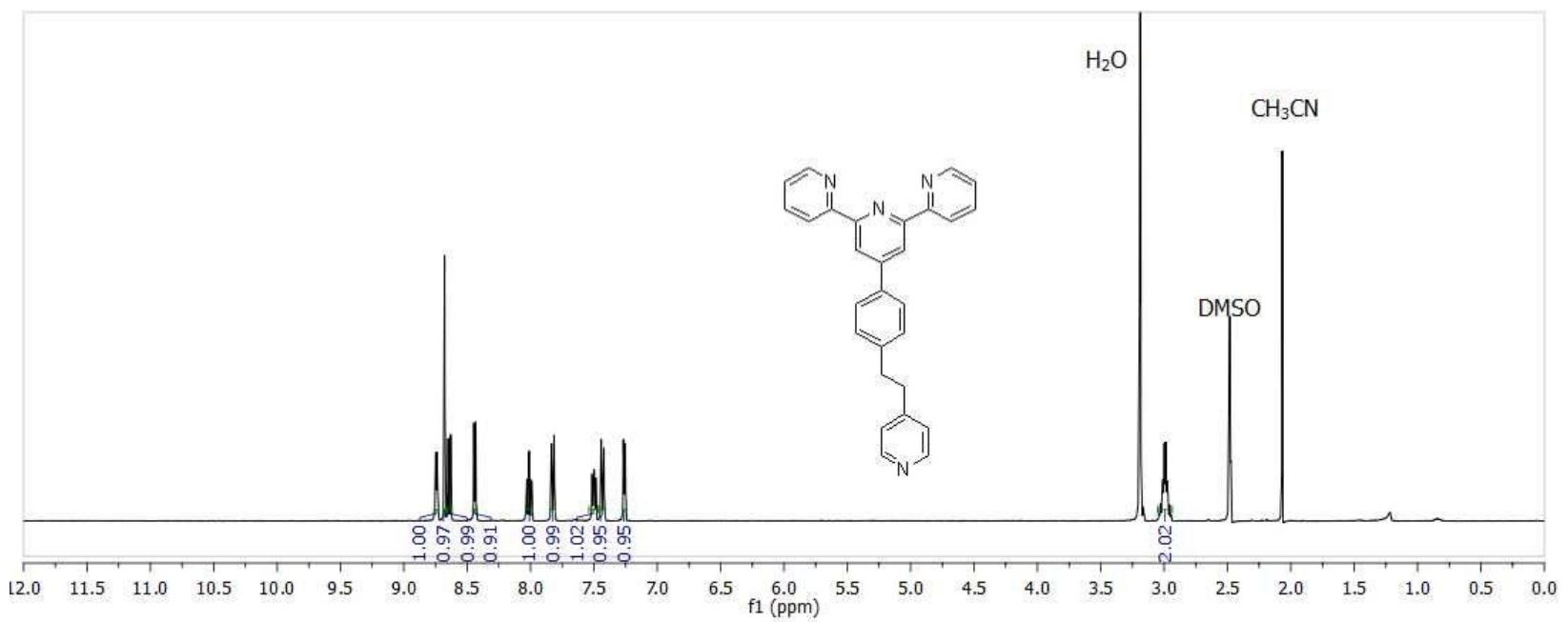

Figure S30: ${ }^{1} \mathrm{H}$ NMR spectrum of s-tpy.

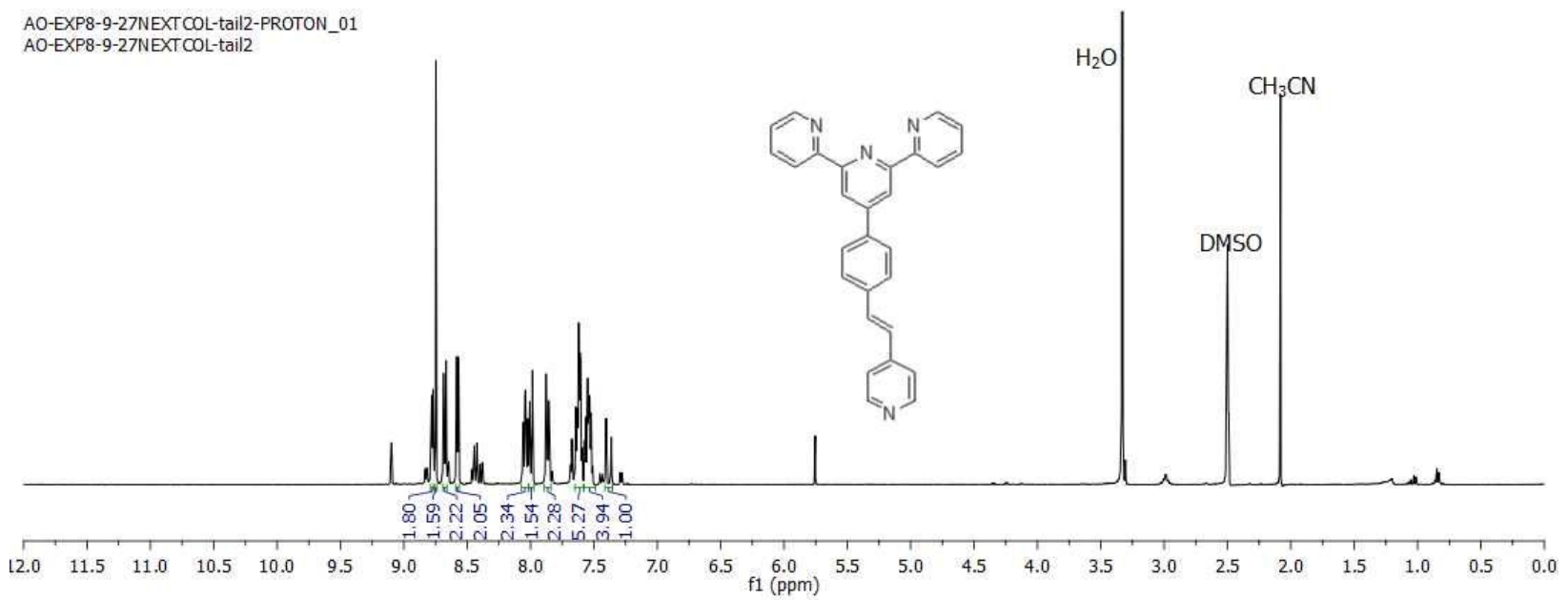

Figure S31: ${ }^{1} \mathrm{H}$ NMR spectrum of d-tpy.

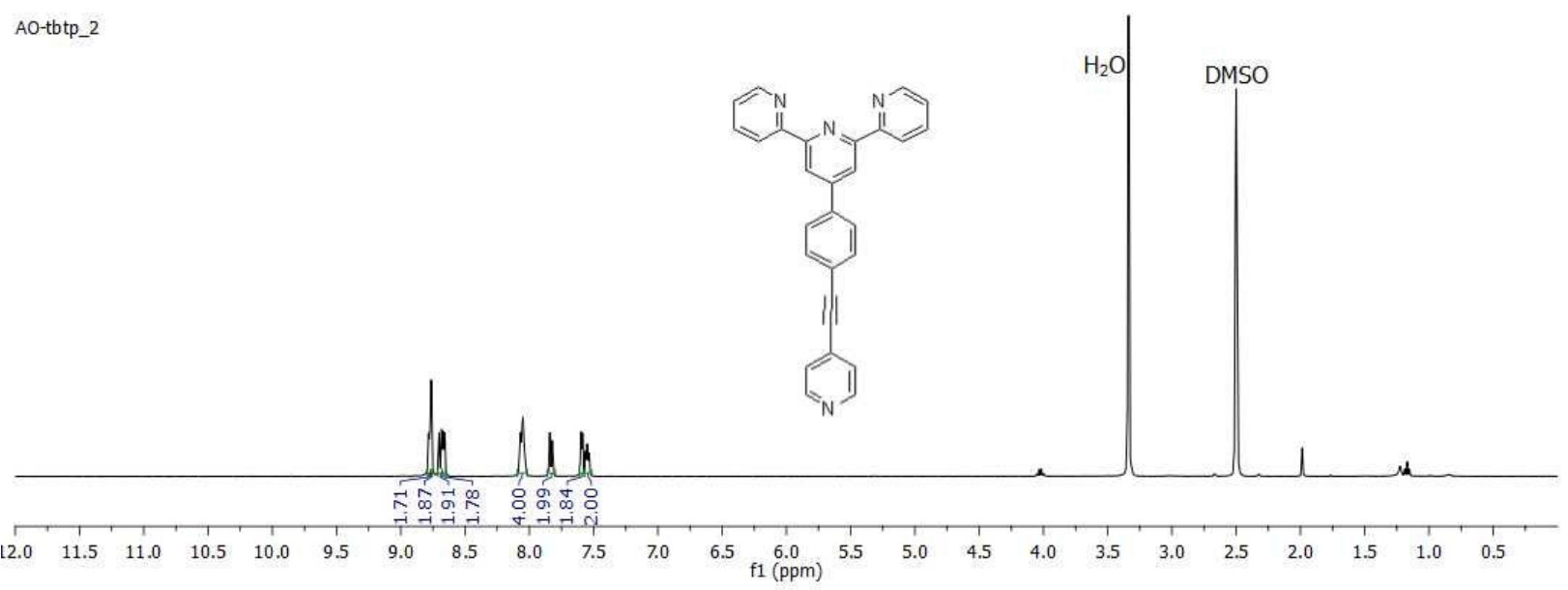

Figure S32: ${ }^{1} \mathrm{H}$ NMR spectrum of t-tpy. 


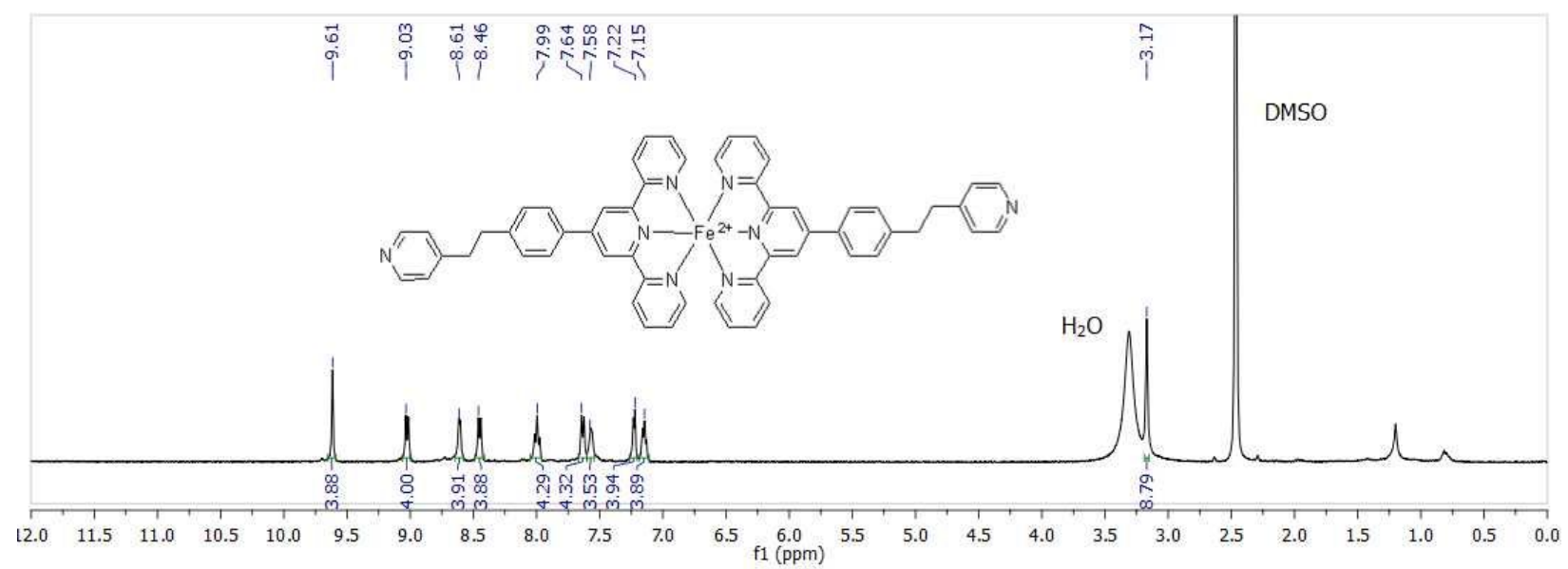

Figure S33: ${ }^{1} \mathrm{H}$ NMR spectrum of $\left[\mathbf{F e}(\mathbf{s}-\mathrm{tpy})_{2}\right]\left(\mathbf{B F}_{4}\right)_{2}$.

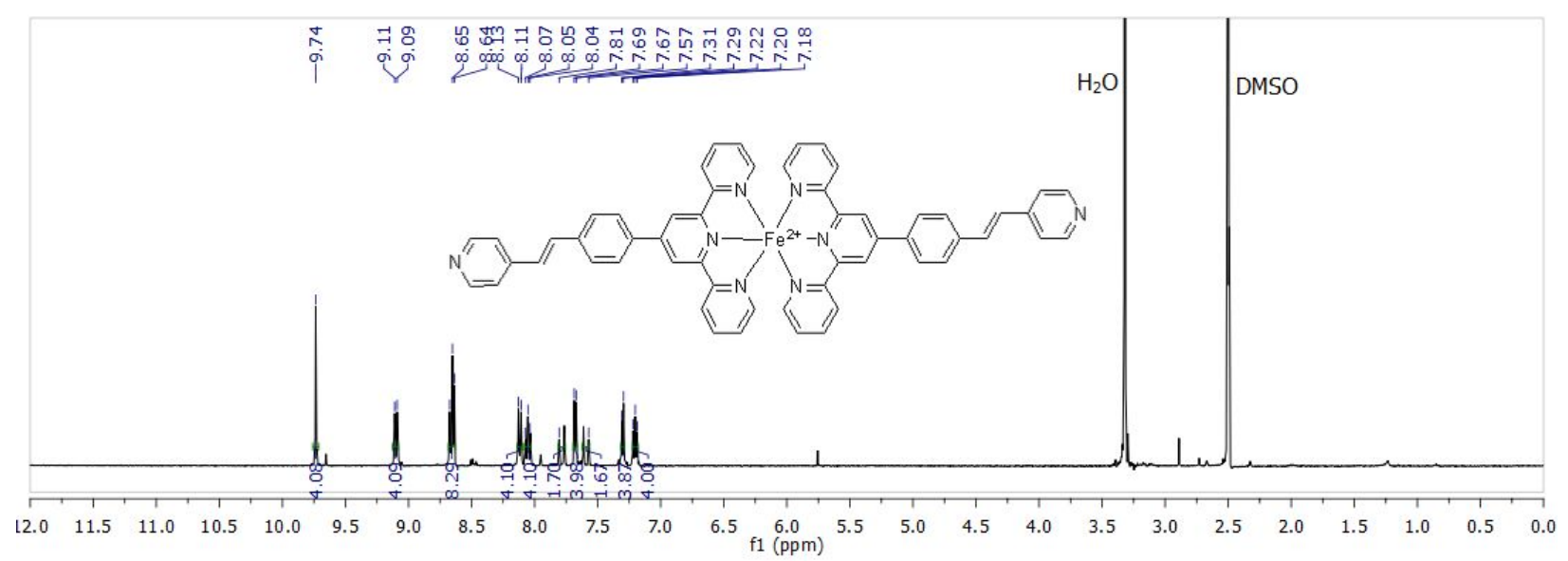

Figure S34: ${ }^{1} \mathrm{H}$ NMR spectrum of $\left[\mathbf{F e}(\mathbf{d}-\mathrm{tpy})_{2}\right]\left(\mathbf{B F}_{4}\right)_{2}$.

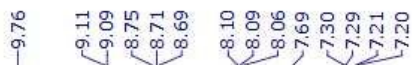

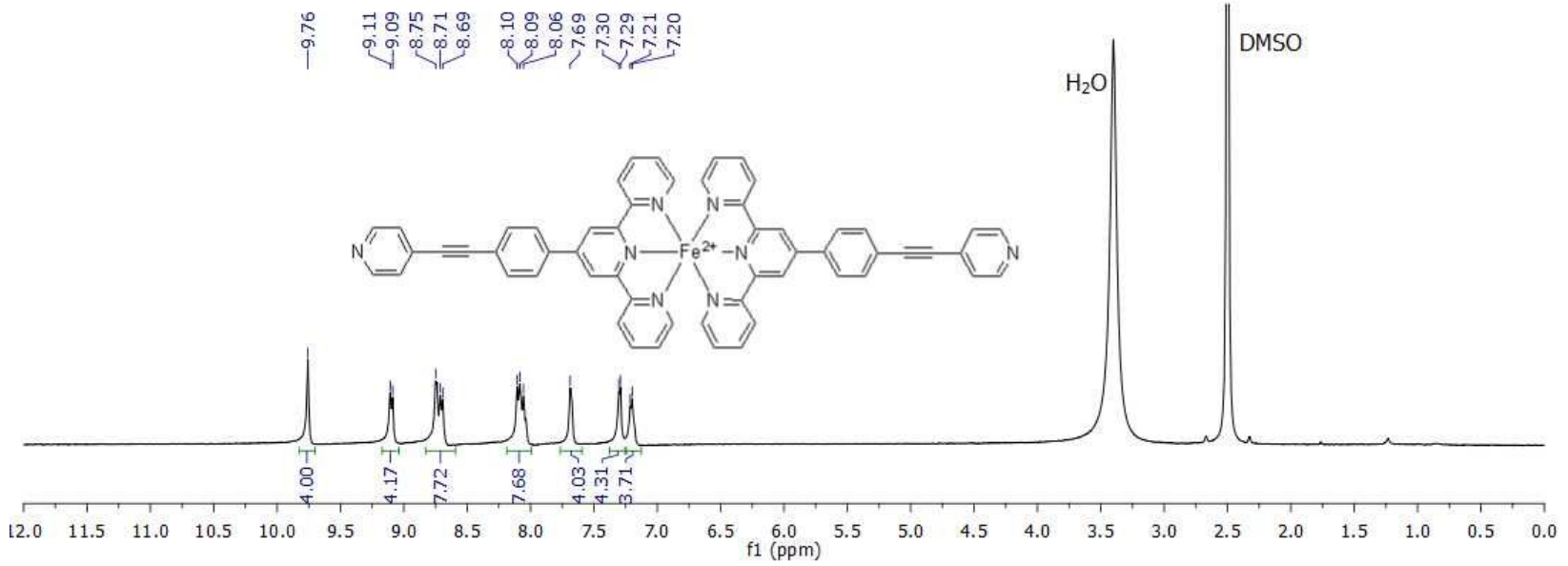

Figure S35: ${ }^{1} \mathrm{H}$ NMR spectrum of $\left[\mathbf{F e}(\mathbf{t}-\mathrm{tpy})_{2}\right]\left(\mathrm{BF}_{4}\right)_{2}$. 


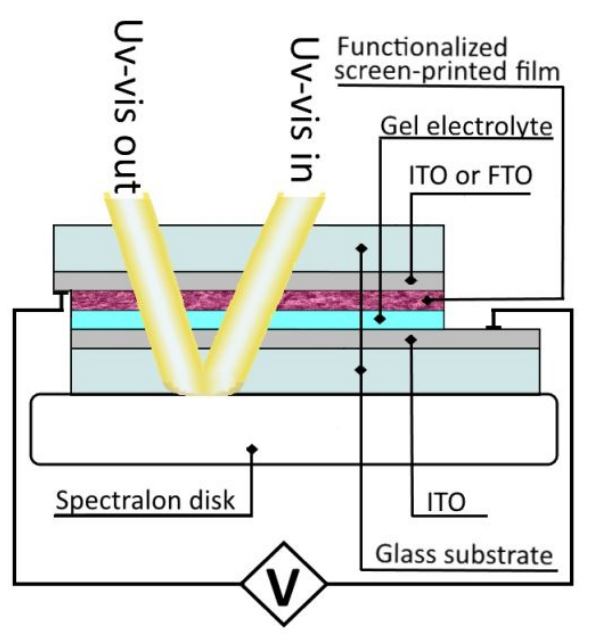

Figure S36: A sketch of solid-state setup of ECDs.

\section{$\underline{\text { References }}$}

(1) Laschuk, N. O.; Ebralidze, I. I.; Poisson, J.; Egan, J. G.; Quaranta, S.; Allan, J. T.; Cusden, H.; Gaspari, F.; Naumkin, F.; Easton, E. B.; Zenkina, O. V., Ligand Impact on Monolayer Electrochromic Materials Properties ACS Appl. Mater. Interfaces 2018, 10 (41), 35334-35343.

(2) Senthilkumar, V.; Vickraman, P.; Ravikumar, R., Synthesis of fluorine doped tin oxide nanoparticles by sol-gel technique and their characterization. J. Sol-Gel Sci. Technol. 2010, 53 (2), 316-321.

(3) Eckermann, A. L.; Feld, D. J.; Shaw, J. A.; Meade, T. J., Electrochemistry of Redox-active Self-assembled Monolayers. Coord. Chem. Rev. 2010, 254 (15), 1769-1802.

(4) Allan, J. T. S.; Quaranta, S.; Ebralidze, I. I.; Egan, J. G.; Poisson, J.; Laschuk, N. O.; Gaspari, F.; Easton, E. B.; Zenkina, O. V., Terpyridine-based monolayer electrochromic materials. ACS Appl. Mater. Interfaces 2017, 9 (46), 40438-40445.

(5) Wang, G.; Zhang, L.; Zhang, J., A review of electrode materials for electrochemical supercapacitors. Chemical Society Reviews 2012, 41 (2), 797-828.

(6) Ricardo Vergaz; J. M. S. Pena; David Barrios; Vázquez, C., Electrical analysis of new allplastic electrochromic devices. Optical Engineering 2006, 45 (11).

(7) Reid, O. R. O.; Saleh, F. S.; Easton, E. B., Application of the transmission line EIS model to fuel cell catalyst layer durability. ECS trans 2014, 61 (23), 25-32.

(8) Reid, O. R.; Saleh, F. S.; Easton, E. B., Determining Electrochemically Active Surface Area in PEM Fuel Cell Electrodes with Electrochemical Impedance Spectroscopy and its Application to Catalyst Durability. Electrochim. Acta 2013, 114, 278-284.

(9) Santos, J. J.; Toma, S. H.; Lalli, P. M.; Riccio, M. F.; Eberlin, M. N.; Toma, H. E.; Araki, K., Exploring the coordination chemistry of isomerizable terpyridine derivatives for successful analyses of cis and trans isomers by travelling wave ion mobility mass spectrometry. Analyst 2012, 137 (17), 4045-4051.

(10) Tran, A. T.; Huynh, V. A.; Friz, E. M.; Whitney, S. K.; Cordes, D. B., A general method for the rapid reduction of alkenes and alkynes using sodium borohydride, acetic acid, and palladium. Tetrahedron Lett. 2009, 50 (16), 1817-1819. 
(11) Saha, M. L.; Bats, J. W.; Schmittel, M., Merging strong and weak coordination motifs in the integrative self-sorting of a 5-component trapezoid and scalene triangle. Org. Biomol. Chem. 2013, 11 (34), 5549-5736.

(12) Goodall, W.; Williams, J. A. G., Iridium(III) bis-terpyridine complexes incorporating pendent N-methylpyridinium groups: luminescent sensors for chloride ions. J. Chem. Soc., Dalton Trans. 2000, (17), 2893-2895. 